\title{
DEVELOPING MYANMAR'S FINANCE SECTOR TO SUPPORT RAPID, INCLUSIVE, AND SUSTAINABLE ECONOMIC GROWTH
}

Vikram Nehru

NO. 430

April 2015
ADB ECONOMICS WORKING PAPER SERIES 
ADB Economics Working Paper Series

\section{Developing Myanmar's Finance Sector to Support Rapid, Inclusive, and Sustainable Economic Growth}

Vikram Nehru

No. 430 | April 2015
Vikram Nehru (vnehru@ceip.org), Senior Associate and Bakrie Chair in Southeast Asian Studies, Carnegie Endowment for International Peace.

This was a background paper for the Asian Development Bank (ADB) Myanmar Country Diagnostics Study. The author is grateful to Jean-Pierre Verbiest and Cyn-Young Park for helpful comments on an earlier draft and to Van Tran and Nadia Bulkin for their research assistance. 
Asian Development Bank

6 ADB Avenue, Mandaluyong City

1550 Metro Manila, Philippines

www.adb.org

(C) 2015 by Asian Development Bank

April 2015

ISSN 2313-6537 (Print), 2313-6545 (e-ISSN)

Publication Stock No. WPS157238-2

The views expressed in this paper are those of the author and do not necessarily reflect the views and policies of the Asian Development Bank (ADB) or its Board of Governors or the governments they represent.

ADB does not guarantee the accuracy of the data included in this publication and accepts no responsibility for any consequence of their use.

By making any designation of or reference to a particular territory or geographic area, or by using the term "country" in this document, $A D B$ does not intend to make any judgments as to the legal or other status of any territory or area.

Note: In this publication, "\$” refers to US dollars.

The ADB Economics Working Paper Series is a forum for stimulating discussion and eliciting feedback on ongoing and recently completed research and policy studies undertaken by the Asian Development Bank (ADB) staff, consultants, or resource persons. The series deals with key economic and development problems, particularly those facing the Asia and Pacific region; as well as conceptual, analytical, or methodological issues relating to project/program economic analysis, and statistical data and measurement. The series aims to enhance the knowledge on Asia's development and policy challenges; strengthen analytical rigor and quality of ADB's country partnership strategies, and its subregional and country operations; and improve the quality and availability of statistical data and development indicators for monitoring development effectiveness.

The ADB Economics Working Paper Series is a quick-disseminating, informal publication whose titles could subsequently be revised for publication as articles in professional journals or chapters in books. The series is maintained by the Economic Research and Regional Cooperation Department. 


\section{CONTENTS}

FIGURES AND BOXES

ABSTRACT $v$ V

$\begin{array}{ll}\text { I. INTRODUCTION } & 1\end{array}$

II. THE LEGACY OF THE PAST 6

III. THE CURRENT STRUCTURE OF THE FINANCIAL SYSTEM 8

IV. FINANCIAL SYSTEM PERFORMANCE 14

V. RECENT AND ONGOING REFORMS 18

VI. NEED FOR A FINANCE SECTOR STRATEGY 20

VII. KEY COMPONENTS OF A FORWARD-LOOKING FINANCE SECTOR

A. $\quad$ Policies and Measures to Increase Banking System Efficiency 22

B. Policies to Promote Financial System Stability 28

C. Policies for a More Inclusive Financial System 31

VIII. SEQUENCING REFORMS FOR FINANCE SECTOR DEVELOPMENT 36

APPENDIX 1: $\quad$ CAPITAL MARKET DEVELOPMENT 39

APPENDIX 2: MICROFINANCE PROVIDERS IN MYANMAR 42

REFERENCES 


\section{FIGURES AND BOXES}

\section{FIGURES}

$1 \quad$ Financial System Structure $\quad 9$

2 Commercial Bank Branches in Low-Income Countries, 2012

3 Commercial Bank Branches in Middle-Income Countries and Myanmar, 201216

4 Borrowers from Commercial Banks in Low-Income Countries, $2012 \quad 16$

$5 \quad$ Commercial Banks' Outstanding Deposits and Loans 23

$6 \quad$ Lending and Deposit Interest Rates, 1976-2012 26

$7 \quad$ Real Lending and Real Deposit Rates, 1976-2012 27

\section{BOXES}

$1 \quad$ State-Owned Development Banks: Lessons of Experience 32

$2 \quad$ Financing Small and Medium-Sized Enterprises $\quad 34$ 


\begin{abstract}
The finance sector is the lifeblood of any economy and its smooth functioning is central to rapid and inclusive economic growth. A well-functioning financial system must intermediate efficiently between savers and borrowers; manage risks prudently; provide a wide variety of financial services to firms, farms, and households; mobilize savings effectively; identify and lend for sound investments; remain robust in the face of shocks; and ensure that access to finance is available to all. This paper presents broad outlines of a reform strategy to develop a stable and efficient finance sector that supports rapid and inclusive growth in Myanmar.
\end{abstract}

Keywords: access to finance, finance sector, inclusive growth, Myanmar, savings mobilization

JEL Classification: E44, G21, G23, G28 


\section{INTRODUCTION}

Myanmar's banking system was the envy of Asia before the country nationalized banks in 1963, when it had 10 domestic and 14 foreign banks - the largest concentration of foreign banks in Southeast Asia at that time.' But until recently, a series of policy shocks had buffeted the finance sector and stunted its development, leaving a legacy of distrust in cash as a unit of value and banks as a secure place to hold wealth.

This paper presents the Government of Myanmar the broad outlines of a reform strategy to develop a stable and efficient finance sector that can again support rapid and inclusive growth. The finance sector is the lifeblood of any economy, and its smooth functioning is central to achieving these goals. A well-functioning financial system must intermediate efficiently between savers and borrowers; manage risks prudently; provide a wide variety of financial services to firms, farms, and households; mobilize savings effectively; identify and lend for sound investments; remain robust against shocks; and ensure that access to finance is available to all.

Banking system structure. Myanmar's financial system now comprises 4 state banks, 22 private banks (nine of which are really semigovernment institutions), 42 representative offices of foreign banks and foreign finance companies, 1 state-owned, and 12 newly licensed insurance companies, and a nascent capital market. While the state banks still dominate, private bank assets now significantly exceed state banks' after rapid growth in recent years. A new microfinance bank was recently established and authorities are considering license applications for a housing bank and a livestock development bank. Because the country does not yet permit foreign direct investment (FDI) in banking, it has representative offices of foreign banks in Yangon, which provide liaison support to clients operating in the country.

Banking system challenges. By most measures, Myanmar's formal financial system is small compared to other countries. Rural areas have limited access to banking services, and bank lending to agriculture is largely restricted to the state-owned Myanma Agricultural Development Bank, which faces financial and operational challenges of its own and covers only a small share of the financing needs of farmers.

The banking system also faces other challenges. Collateral-based lending inevitably restricts lending to land holders, although the government recently expanded collateral options to include key agricultural export goods. State-imposed social responsibilities encumber state banks, which consequently have little incentive to manage risk and are in parlous financial condition. Dynamic private banks, meanwhile, are rapidly losing market share of lending to businesses. Private banks also have shortcomings. Closely integrated private commercial groups own most of them, and consequently, their loan portfolios tend to be concentrated within these groups, which can mask large risks.

Growth of the financial system in general and the banking system in particular is also constrained by weaknesses in basic institutional systems and infrastructure. The financial system especially needs an automated payments clearance system, a money market system comprising an

\footnotetext{
The 10 Burmese banks were Innwa Bank, Export Import Bank, Union Cooperative Bank, Rangoon Bank, Burmese National Bank, Myanmar Eastern Bank, Burmese Economic Bank, Myanmar Central Commercial Bank, Tavoy Bank, and Upper Burma Bank. The 14 foreign banks were India Central Bank, Chartered Bank, Habib Overseas Bank, India Overseas Bank, Mercantile Bank, United Commercial Bank, Punjab National Bank, India State Bank, Hong Kong and Shanghai Banking Corporation, National and Grindlays Bank, Communication Bank, China People's Bank, Netherlands Trading Association Bank, and the Overseas Chinese Banking Corporation.
} 
interbank market, a bond market, a repo market for modern liquidity management, and an electronic real-time data system that connects commercial and development banks with the central bank (Nijathaworn et al. 2015).

Ongoing banking reforms. The government has made swift progress in reforming the policy and institutional environment for the finance sector since the launch of broad economic reforms. Most significantly, it liberalized the foreign exchange market and approved a new FDI law, with accompanying rules and regulations. The government has also made concerted effort to improve the country's financial infrastructure by enacting new laws to strengthen the financial system, most notably the Central Bank Law and the Securities Exchange Law. It has launched programs with the support of technical assistance from the international community to introduce an interbank clearance and settlement system, establish a stock exchange, strengthen bank supervision, develop the foreign exchange market, and prepare a finance sector development master plan.

The need for a finance sector development strategy. The rapid development of the finance sector, while ensuring stability, efficiency, and increasing access to financial services, is now the priority. To achieve these objectives, the government needs to prepare a finance sector development strategy, using as a starting point the master plan it is preparing with the help of the International Monetary Fund (IMF) and the World Bank. The strategy should focus on three objectives-increasing finance sector efficiency, stability, and inclusion. It could also include the following elements:

Key reform priorities for finance sector development. The highest priority in the financial system is to build strong institutional foundations for the banking system that will improve the efficiency of financial transactions and improve their safety and security. These would include:

i. An automated clearance system. The authorities are implementing this with the assistance of the Japan International Cooperation Agency (JICA). Banks in Myanmar spend a lot of time moving large amounts of cash from bank to bank, branch to branch, and to and from the central bank, with a lot of time and labor devoted to counting money at each of these points (which, despite counting machines, are prone to errors). Introducing a clearance system for checks will significantly improve banking efficiency.

ii. An automated payments system. The Central Bank of Myanmar (CBM) is introducing this with JICA's help, in tandem with the clearance system (due to start in 2015). The payments settlement system and the clearance system have to be fully consistent to ensure that transfers between banks occur immediately after checks clear.

iii. A money market system. The next steps for this include the introduction of new short-term central bank financial instruments and an auction system; an interbank market together with a repo market to ameliorate counterparty risk, CBM liquidity facilities for when the interbank market proves inadequate, and application of reserve requirements and judicious use of liquidity ratios. The IMF and the World Bank are providing technical assistance to the CBM in all these areas.

iv. A credit information system. This should have legal protection to encourage its activities, integrity of the database, and that information is used only to advance public policies, privacy, and enforcement and supervision.

v. Financial accounting standards. All banks and corporates should eventually use the Myanmar Financial Records Standard (MFRS) and make public their audited bank balance sheets and income statements.

Enhancing the role of FDI in deliberate steps. The entry of foreign-owned banks into Myanmar's financial system is desirable because of the potentially beneficial effects for the banking 
system's efficiency and modernization. But the authorities need to be careful at this stage of the country's financial development that a sudden entry of foreign banks does not exacerbate systemic finance sector risks. Given weak portfolios in many domestic banks and the absence of a strong regulatory and institutional framework supportive of stability and risk management in the banking system, it would be best to phase in the entry of foreign banks. The authorities could begin by encouraging strategic partnerships and joint ventures, and then proceed to minority foreign shareholdings in domestic banks. As conditions permit, licenses could then be issued for majority foreign-owned banks. This policy transition could take many years, as it will depend on the development of the institutional and regulatory system, and the speed with which domestic banks acquire adequate financial and competitive strength. However, if the government allows the full foreign ownership of banks immediately, it may need to apply ceilings on the market share that foreign banks can acquire in the initial years to prevent their entry from generating systemic risks in the domestic financial system.

Phasing in a new interest rate policy. Liberalizing interest rates too early in the absence of a strong financial infrastructure and a supervision and risk management system can lead to risky bank behavior and exacerbate systemic risks. The authorities should carefully consider the sequencing of these actions. First, the CBM should continue to determine the interest rate structure administratively, but take care that banks earn positive real returns on deposits and have an adequate intermediation margin. Second, when the CBM's capabilities are well-developed and a suitably strong financial infrastructure is in place, the central bank could consider replacing a fixed interest rate structure with a floor for lending rates and a ceiling for interest rates. This will gradually introduce some competition among banks on the price of capital (at the margin). Finally, after perhaps a decade or two of strong finance sector development, the government could consider liberalizing lending rates first and then, later, liberalizing deposit rates. This last stage, however, should not be a current concern for policy makers.

Consolidating the number of private banks. Given Myanmar's stage of development, the number of commercial banks appears to be more than ample. Allowing more bank entrants at this stage would lower franchise values, encourage risky behavior, and increase the probability of bank failures. Instead, the authorities should encourage mergers between banks to reduce their numberand start with the state banks.

Applying regulations equally to state and private banks. To encourage competition between banks, the CBM and the government should ensure that laws and rules relating to the finance sector apply equally to state banks and private banks. Another reform to encourage competition could be to allow banks that bid successfully at foreign exchange auctions to indicate an account of their choice for depositing auction-bought foreign exchange. To find other efficiency enhancing solutions, the CBM should regularly consult with the private banks and with representatives of the public and enterprises.

Restructuring state banks and semigovernment financial institutions. In due course, the government should return to the CBM and the Ministry of Finance all central banking and treasury functions performed by state banks, so that state banks can focus on their banking activities. In addition, state banks, as well as the nine semigovernment financial institutions, need to undergo thorough international-standard financial and performance audits (financed by donor grants). The audit results should be the basis for preparing a forward-looking strategy for their restructuring, which could include closure, merger, privatization, or transformation into one, or at most two, well-financed and clearly focused development banks (or credit guarantee agencies). 
Establishing state-owned development banks. The government's decision to establish a development bank will link closely to its restructuring program for state banks. Those that survive should focus on development banking, leaving commercial banking to the private sector. If the government does decide to proceed with a development bank arrangement, such as a credit guarantee scheme for lending to small and medium-sized enterprises (SMEs), it should do so in partnership with organizations such as the International Finance Corporation (IFC) or the Asian Development Bank (ADB). It should also build on the experience of other Asian countries, particularly Indonesia, Malaysia, and Thailand.

Strengthening the CBM's supervisory capacity. The CBM, with the support of grant funding from the donor community, should consider hiring 20 world-class banking supervisors from neighboring Asian countries for about 5 years. These supervisors could kick-start the CBM's supervision capacity (and the adherence of banks to MFRS), and train CBM supervisors who can then take over all supervision responsibilities within the 5 -year period.

Streamlining regulations. The CBM's reform of its regulatory framework should focus on moving from direct, ex-ante approvals of transactions to indirect, ex-post supervision to ensure banks operate responsibly and within the CBM's guidelines. In addition, the central bank should conduct an audit of all bank regulations and eliminate those serving little purpose. If adopted, this would be an ongoing process and the authorities should seek the support of advisors from the international financial institutions, as well as from neighboring central banks.

Developing a risk management framework. The authorities should establish a department within the CBM that identifies insolvent banks, assists in winding down their operations in an orderly fashion, and ensures that depositors (especially small depositors) are protected in the process, and that any risks are not transferred to other banks or financial institutions. In other words, authorities should not wait until insolvent institutions become illiquid and precipitate a systemic banking crisis.

Establishing a deposit insurance system. Depositors have limited information about the risk and value of bank assets, which can lead to bank runs and contagion in times of financial stress. Deposit insurance can limit the risk of bank runs by guaranteeing that depositors will receive some, or all, of their funds if banks become insolvent or illiquid. Deposit insurance protection can only be successful if there is an effective supervisory, regulatory, institutional, and financial framework in place. This will take some time to develop in Myanmar. In the meantime, with the assistance of international financial institutions, the government should study the feasibility of a deposit insurance scheme and the needed preparatory steps to build a deposit insurance system that borrows from good practice in developing economies at a similar stage of financial development.

Developing the capital market. This will eventually be composed of the money, government bond, corporate bond, and equity markets. However, developing all these will take many years, even decades. The government's immediate focus should be to develop the money market to help banks and other financial institutions manage liquidity, and to provide the foundation for establishing a government bond market. It should also begin preparing the legal and institutional infrastructure for the bond market. This will entail establishing a primary dealer system, as well as a safe and secure secondary market system, building a broad investor base, and preparing a steady pipeline of debt securities based on a credible government debt strategy. Work on developing the corporate bond and equity markets should only begin once the money and the government bond markets are fulfilling their roles efficiently, which could be several years away. In the meantime, the government should press ahead with mandating that corporations meet MFRS accounting standards, subject their accounts to external audit, and make their audited accounts publicly available. 
Easing restrictions on new bank branches. While the CBM has significantly eased regulatory requirements to open new branches, considerable room remains for reform in this area. For example, there is no need to impose a constant ratio of the capital base to the number of branches, which will require that banks inject more capital each time they open a branch. Since private banks must compete on service standards, the CBM needs to recognize that these banks have every incentive to identify branches that will improve service standards and ensure prudential safeguards. The CBM should focus on the overall prudential standards for banks and occasionally visit banks to see that their systems meet CBM standards.

Reconsidering the strategy for microfinance. The rapid expansion of the microfinance network in Myanmar poses financial risks to the overall financial system. The government should immediately place a temporary moratorium on new licenses for microfinance institutions, and then carefully review developments in the microfinance sector, as well as the current institutional arrangements for licensing and supervision. Based on these findings, the CBM should recalibrate its strategy for microfinance institutions, as needed, to ensure a sustainable and vibrant microfinance system.

Encouraging branchless banking. A growing body of analysis points to the many benefits of branchless banking, and many of Myanmar's private banks are gearing up to introduce it. Expanding access to banking services through innovative approaches will help Myanmar's banks increase efficiency and access to finance. This need not result in financial instability if the authorities combine appropriate regulatory and supervisory safeguards with market liberalization policies. One particular issue, however, needs careful handling-the CBM must continue to emphasize know-your-customer requirements for financial institutions to ensure Myanmar complies with international standards for antimoney laundering and combating the financing of terrorism.

Sequencing finance sector reforms. This paper also recommends sequencing for these reforms so they address critically binding constraints to finance sector development and ensure reform does not overburden Myanmar's scarce administrative and banking skills. Sequencing should initially emphasize building the financial infrastructure to underpin the banking system, finalizing the legal framework, introducing clearance and settlement systems, strengthening the CBM (especially its supervision capacity), establishing a money market, easing restrictions on new bank branches, and preparing the ground for deeper structural changes in the banking system. Authorities should ensure that foreign investment in the banking system occurs slowly and in stages to be consistent with the strength of the regulatory framework and the efficiency and reach of domestic banks. Similarly, interest rate reform should proceed in stages; in the early years of the first stage, the interest rate structure should be determined administratively and adjusted periodically to keep interest rates positive in real terms as macroeconomic conditions demand.

The second stage of reforms, over the short- to medium-term, should focus on broader structural changes in the finance sector. These should include restructuring state banks and semigovernment financial institutions - and either closing, merging, or transforming them into one-or at most two state-owned development banks - and implementing a revamped microfinance strategy. The second stage should also include developing an operational framework to deal with systemic risks; establishing a government bond market and its prerequisites, which include legal, regulatory, and institutional infrastructure; preparing the regulatory and legal framework for branchless banking; and putting in place a deposit insurance system. 
Consistency with other reforms. Myanmar's finance sector reforms will be taking place alongside reforms in other sectors and it is important that all are consistent and coordinated well. ${ }^{2}$ Pragmatism demands that the government move ahead with finance sector reforms while reforms in the real sector also get started. But it must ensure that any disruptions in the real sector do not raise banks' nonperforming loan ratios above prescribed prudential limits. Even more importantly, policies to strengthen Myanmar's fiscal performance will have major bearing on the outcome of finance sector reforms. Strengthening the government's fiscal position will mean less pressure on the financial system to play a quasi-fiscal role. It will also ensure that adequate government resources are available to finance state bank restructuring, establish a development bank, deal with systemic risks in the banking system, and prevent crowding out of the finance sector.

The intention of this paper is not to provide a blueprint, but rather to indicate the issues that need addressing and offer ways to address them. The first of its two main sections describes the legacy of the past and the current components of the financial system, key features of current finance sector policies, and ongoing reforms. The second sets out the main elements of a finance sector reform strategy, together with how authorities could sequence these reforms and their possible interaction with reforms in other parts of the economy.

For clear direction and sequencing of reforms, the government needs a finance sector development strategy with the following five important characteristics:

i. Base the strategy on a thorough and objective understanding of the financial system as it functions today.

ii. Clearly articulate the objectives of the strategy and ensure they are acceptable to all relevant stakeholders.

iii. Recognize that not everything can be done at once and so the strategy should adopt a step-bystep approach that ensures binding constraints to finance sector development are addressed first. The corollary of this will be to accept that while binding constraints are being addressed, other less important reforms may need to wait.

iv. Evaluate regularly and objectively to inform mid-course corrections in the reform strategy, as needed.

v. Sequence the strategy with reforms in other parts of the economy, notably in exchange rate and fiscal policies, and in the real sector.

\section{THE LEGACY OF THE PAST}

Among banks operating in Myanmar, before the nationalization of 1963, were such global banking majors of the times as Chartered Bank, ${ }^{3}$ National Grindlays Bank, and Hong Kong and Shanghai Banking Corporation.

A series of policy shocks buffeted the sector thereafter, however, undermining trust in cash as a unit of value and in the security of banks, as noted in the introduction. Of the many events that shaped the country's banking system, this section highlights six particularly important shocks.

For a detailed discussion of the role of the finance sector in developing countries, see Hermes and Lensink (2013).

Chartered Bank became Standard Chartered Bank after merging with the Standard Bank of South Africa in 1969. 
- Nationalization of banks in 1963. After the military takeover in 1962, the new government on 26 February 1963 ordered the nationalization of all private banks, eventually incorporating them into four state banks. The nationalization of most large enterprises followed. The number of state economic enterprises grew rapidly, as a result, and by the early 1980s, their expenditures accounted for around $50 \%$ of gross domestic product (GDP). Most state economic enterprises faced "soft budget constraints" in which managers had little incentive to make profits, since the government pressured state banks to extend loans to cover losses.

- Demonetization of 1985-1987. In 1985, the Ne Win administration introduced a 75-kyat note and 15- and 35-kyat notes in the following year. The government, at the time, demonetized the 50- and 100-kyat notes in circulation, following a grace period, during which citizens could exchange some of their old notes for new ones. However, in September 1987, the government issued a series of 45- and 90-kyat notes and demonetized the 25-, 35-, and 75-kyat notes. ${ }^{4}$ This time, two-thirds of the value of all cash in circulation was effectively declared illegal with no option to convert existing notes into the new currency. Sporadic protests broke out among students unable to pay their university fees and, by 1988, these had become widespread, ultimately forcing General Ne Win to step down and triggering a bloody army crackdown on 8 August 1988 (Egreteau 2009). The demonetization instilled widespread reluctance to hold currency. Farmers hoarded crops, while others bought what physical assets they could, such as commodities (including gold), land, and even manufactured goods, with whatever domestic currency they possessed.

- Partial liberalization in the 1990s. During the early 1990s, the military leaders who succeeded General Ne Win in 1988 introduced a partial liberalization of the domestic economy; as part of that process, private banking was restarted. In 1990, the government promulgated the Central Bank of Myanmar Law and the Financial Institutions of Myanmar Law, and the first private bank (Myanmar Citizens Bank) commenced operations in June 1992. By the end of 1992, four private banks were in business, and another four in 1993. By the end of 1997, Myanmar had 20 private banks.

- The banking crisis of 2003. Given the lack of transparency at the time, its origins are somewhat obscure, but it is thought to have started with the collapse of a number of trading companies that were acting as informal financial institutions. The contagion spread to banks, which were subsequently instructed to pull back all their loans to increase their own liquidity, which, in turn, created a real sector depression that further eroded the value of financial assets. Yoma Bank, the second largest private bank in 2003, could not withstand the abrupt and massive withdrawal of deposits and had to resort to central bank support. Yoma Bank curtailed operations, but it was allowed to remain open purely for the transfer of remittances. It took Myanmar until 2007 to recover from the banking crisis.

External factors exacerbated the domestic causes of the crisis. On 3 November 2003, when the crisis was still ongoing, Financial Action Task Force, an international initiative to prevent money laundering and counter the financing of terrorism, imposed "additional countermeasures" on Myanmar because of the country's continuing failure to address "major deficiencies in its antimoney laundering regime" (OECD 2003). A week later, the United States (US) Treasury announced that the Mayflower Bank and the Asia Wealth Bank were of

4 The reasons behind the move were many. One was to lower inflation by reducing the stock of money in circulation. Another was to render stockpiles of notes held by insurgent groups worthless. A third was to destroy the black market. Unfortunately, demonetization achieved none of these aims, but instead caused widespread distress. 
"primary money-laundering concern." It directed US financial institutions to take "special measures" against the two banks, and took special action itself on grounds that the two banks were facilitating money-laundering operations for drug trafficking organizations (Federal Register 2003).

- Closure of Universal Bank in 2005. On 5 August 2005, troops closed and sealed branches of the Myanmar Universal Bank, the chair and managing director were arrested, and Myanma Economic Bank eventually absorbed the bank. It is still not clear what prompted this government action. Some suggest the bank was involved in money laundering, which the government wanted to stop; others claim the action was to punish the bank's owners for being too closely connected to the previous prime minister, who had just been deposed and arrested on corruption charges (The Irrawaddy 2005).

- The minicrisis of 2012. On 5 October 2012, following a rumor spread through social media, there was a run on KBZ Bank, Myanmar's largest private bank. Prompt action by the CBM, which included media statements emphasizing the financial soundness of all banks and the central bank's willingness to guarantee their finances, helped quell the panic. The episode was a reminder of the fragility of the banking system, but also highlighted the important role appropriate central bank policies can play in ensuring stability.

Implications for the current banking system. The policy and internal shocks that Myanmar's finance sector suffered left several legacies, the most severe of which is a lack of public trust in the banking system. The shocks left the banking system fragile and vulnerable to small shocks. At the same time, the CBM, which was only recently made an independent institution, remains a product of its past. It has limited capacity and has never had the mandate or the authority to oversee state banks. It is institutionally suspicious of the private banking system and its motivations, as reflected in many direct central bank restrictions on private banking activity, including strict limits on acceptable collateral for loans, loan maturity, interest rates and fees, branch openings, and daily reporting of financials. The emphasis on ex ante controls has meant the CBM has not developed the capacity to implement indirect prudential regulations that give banks discretion to intermediate funds within well-defined risk parameters and ensure their adherence to these regulations through offsite and onsite supervision (Nijathaworn et al. 2015).

\section{THE CURRENT STRUCTURE OF THE FINANCIAL SYSTEM}

Figure 1 presents the main components of Myanmar's financial system, which as the introduction notes, comprises 4 state banks, 22 private banks (nine of them really just semigovernment institutions), 42 representative offices of foreign banks and foreign finance companies, 1 state-owned, and 12 newly licensed insurance companies, 4 private leasing companies, and a nascent capital market. 


\section{Figure 1: Financial System Structure}

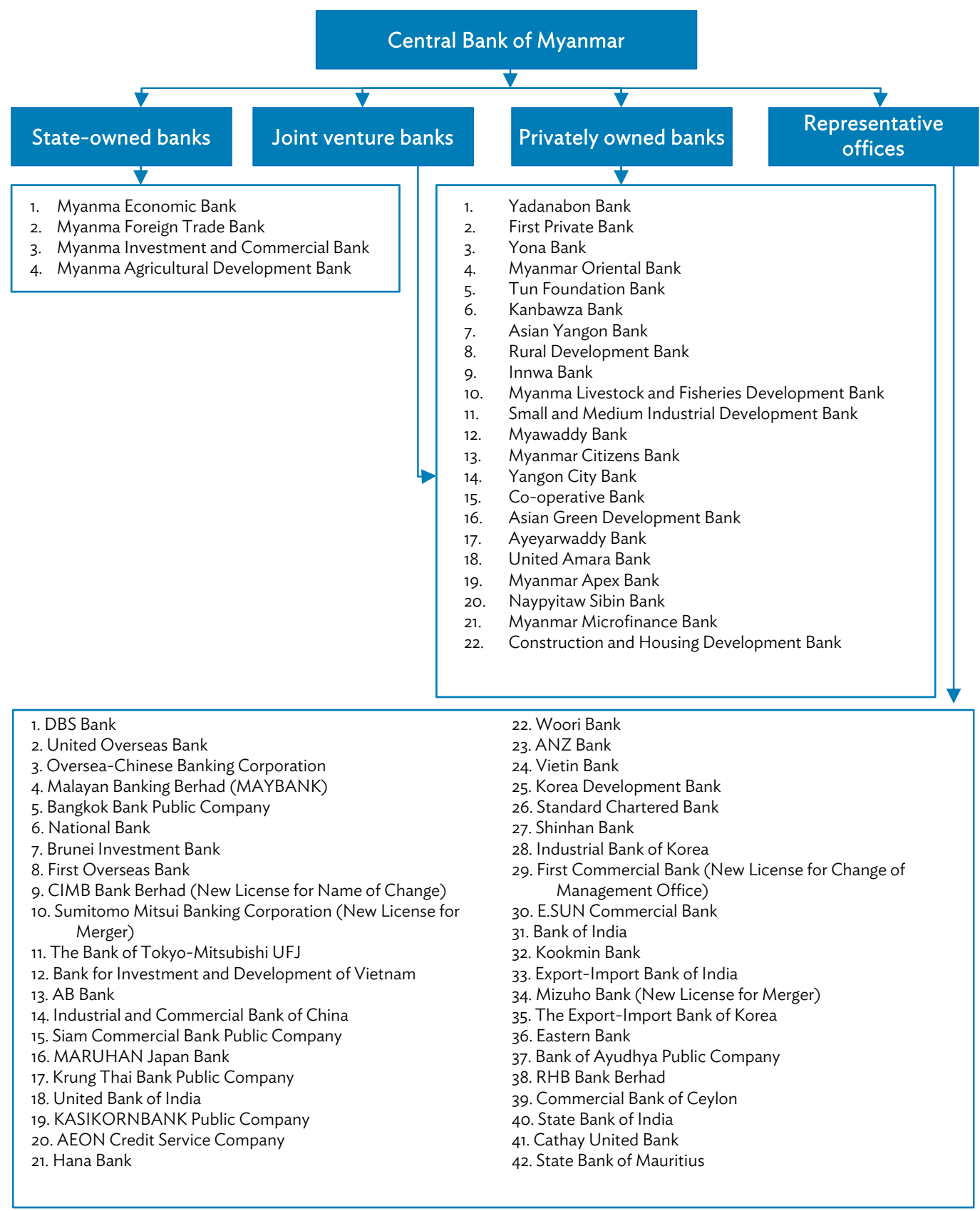

Note: AEON Credit Service Company is a representative office of a finance company, not a bank. In October 2015, nine foreign banks were awarded bank licenses to operate in Myanmar.

Source: Central Bank of Myanmar 2014.

The latest available data (for 2010) show that while the four state banks dominate, private assets now significantly exceed those of the state banks (See table below). The following is a brief overview of the four state banks:

- Myanmar Economic Bank started operations in 1976 under the Bank Law of 1975. It subsequently assumed a new legal identity under the Financial Institutions Law of 1990, which 
superseded the Bank Law of 1975 . The bank shoulders several development and social functions on behalf of the government, and is the principal banking vehicle for lending at concessional interest rates to state enterprises, cooperative enterprises, and other state banks and organizations. The latter includes, for example, Myanma Agricultural Development Bank, the Myanmar Small Loans Enterprise, and the Government Employees Bank, which provides interest free housing loans for civil servants. Myanmar Economic Bank has increasingly been providing banking services to the private sector as well as foreign exchange and trade-related financial services. But close control by the Ministry of Finance and conservative lending practices (the loan-deposit ratio is low) has meant high losses. The bank also provides treasury functions as part of the Ministry of Finance and Revenue, which accounts for Myanmar Economic Bank's extensive network of 320 branches, the largest in the country.

- Myanma Foreign Trade Bank was also established by the government under the Financial Institutions Law of 1990. Its mandate is to provide trade finance and foreign exchange related banking to the government, state enterprises, and the international community residing in Myanmar. It is also responsible for managing the country's official foreign currency reserves. Prior to the recent economic reforms, Myanma Foreign Trade Bank's monopoly access to foreign exchange and its captive market meant that it did not have to compete for clients. As a result, service standards were considered very weak (even in Myanmar's uncompetitive banking sector). The bank is shrinking and losing its relevance, now that the CBM is responsible for managing its own foreign exchange reserves, and that most banks, including private banks, have access to foreign exchange, and some have begun financing foreign exchange related activities. Although Myanma Foreign Trade Bank still has a competitive edge through its 140plus correspondent banking relationships worldwide, its private bank competitors are rapidly establishing and expanding their own overseas networks. It is only a question of time before even this element of the bank's remaining competitive edge evaporates.

- Myanma Investment and Commercial Bank was a part of Myanmar Economic Bank until 1990, when it became a separate entity under the Foreign Institutions Law of 1990. With branches mainly in Yangon and Mandalay, its primary focus is business and its mandate to provide domestic currency denominated loans for commercial, investment, and development activities, as well as to act as a banking intermediary for foreign investment activities.

- Myanma Agricultural Development Bank, run by the Ministry of Agriculture, provides institutional credit to small-scale farmers in its capacity as a government agency. It was created under the Myanma Agricultural and Rural Development Bank Law of 1990 to provide banking services for agriculture and was set the specific task of promoting agricultural, livestock, and rural enterprises, including processing and production. Legally, it is not obliged to follow the requirements of the Financial Institutions Law of 1990, but it does so in some key areas, including the structure of its interest rates. Clients receive 10\% interest on their deposits and may borrow four times their savings at 15\% interest, provided they use the funds for farm development.

The bank_has three types of loans: short-term, designed to finance the cultivation of one crop; medium-term, with short maturities of 1 to 4 years; and long-term, with maturities of up to 10 years (though these constitute a negligible share of the overall loan portfolio). It extends most short-term cultivation loans to farmer groups that are jointly liable for repayment; here, peer pressure replaces collateral to encourage repayment. Term loans, on the other hand, are secured by collateral, which cannot be land (as all land is the property of the state). Loan sizes are usually small in relation to farmer needs. This is in part because of the limitations imposed 
by collateral requirements, but also because of the bank's somewhat parlous financial condition. Being a part of the Ministry of Agriculture, the bank encourages farmers to use their loans to purchase seeds, services, fertilizer, and equipment supplied by the ministry rather than private sellers. Myanma Agricultural Development Bank's rural financing responsibilities require it to run 14 regional offices, 164 branches, and 48 agency offices, most of which are colocated with ministry offices and service centers.

Assets by Bank Type, 2010

\begin{tabular}{|c|c|c|c|}
\hline Type of Bank & $\begin{array}{l}\text { Number } \\
\text { of Banks }\end{array}$ & $\begin{array}{c}\text { Assets } \\
\text { (Kyat billions) }\end{array}$ & $\begin{array}{c}\text { Assets } \\
\text { (\% of GDP) }\end{array}$ \\
\hline State banks & 4 & $1,037.56$ & 3.07 \\
\hline Private banks & 19 & 1,891.31 & 5.06 \\
\hline $\begin{array}{l}\text { Representative } \\
\text { offices }\end{array}$ & 28 & $\ldots$ & $\ldots$ \\
\hline Total & 51 & $2,928.87$ & 8.13 \\
\hline
\end{tabular}

... = not applicable, $\mathrm{GDP}=$ gross domestic product.

${ }^{a}$ As of end-2013.

Source: Min 2011.

Capital adequacy requirements for state banks are lower than for private banks, and state banks (unlike private banks) are not subject to onsite supervision, although no exceptions are made in regulations or instructions. State banks are not restricted in number of branches, whereas private banks are required to increase their capital each time they open a new branch. Managing directors of three state banks are on the CBM's board of governors (together with the bank's governor and one deputy governor). The authority of the managing directors of the three state banks occasionally exceeds that of the CBM's governor, which makes it very difficult for the central bank to properly supervise the state banks.

The Financial Institutions Law of 1990 included regulations that permitted the establishment and operation of private banks. This was the first of a three-stage reform program initiated in that year to liberalize private banking. The next two stages, which have so far not been implemented, involved permitting private banks to form joint ventures with foreign banks and allowing foreign banks to operate independently. It was not until 1992 before the first private banks became operational.

Not all private banks are fully private; for example, nine of the Myanmar's 22 banks are semigovernment institutions. They include the following:

- Myawaddy Bank is a private bank, but wholly owned by Union of Myanmar Economic Holdings, a military-run conglomerate, which in turn is ultimately owned by the Ministry of Defence and its retired staff. The Directorate of Procurement of the Ministry of Defense holds $40 \%$ of Union of Myanmar Economic Holdings' share capital, with serving military personnel, various armed forces' cooperatives, regimental associations, and veterans groups holding the remainder. The management of Union of Myanmar Economic Holdings comprises senior figures within Myanmar's armed forces. Myawaddy Bank's head office in Yangon is located in a building that was once the headquarters of CBM, reflecting its close links to the military government prior to 2011. The bank does substantial business with local and semigovernment bodies, including the Yangon City Development Committee and the Border Areas Development Association. In 2005, Myawaddy Bank's semi-official status brought it under the purview of the United States (US) and European Union's sanctions against the Myanmar 
state-owned enterprises. These included travel restrictions by the bank's senior officials, as well as prohibitions against US and European individuals and entities from investing in the bank.

- Small and Medium Industrial Development Bank is a public company, but managed by government officials (for example, its chair is always the Minister of Industry), and most procedures are typical of a government organization. Formerly known as Myanmar Industrial Development Bank founded by the Myanmar Industrial Development Council, the bank was set up in 1995 to promote industrial development zones. As a result, the bank mainly provides financing assistance for SMEs in industrial zones throughout the country, usually through 3year loans at an interest rate of $8.5 \%$ a year. Collateral requirements are very similar to those in private commercial banks. The bank receives technical assistance from GIZ, the German technical assistance agency, and recently signed a cooperation memorandum of understanding with the Industrial Bank of Korea.

- Myanmar Citizens Bank was the first so-called private bank to be established in 1991 following the promulgation of the Financial Institutions Law of 1990. It began operations on 2 June 1992. In reality, the bank is government-owned, with the government's shareholding administered through the Ministry of Commerce. It is considered a medium-sized bank and is listed on the Myanmar Securities Exchange Center. As of January 2013, it had 255 employees and 8 branches.

- Cooperative Bank operates under the Ministry of Cooperatives and result from a merger of three cooperative banks in 2004. The three banks-CB Bank (established in 1992), Cooperative Farmers Bank (1996), and 'Co-operative Promoters Bank (1996)-ceded to Cooperative Bank several branches across the country making it one of Myanmar's largest banks. The merger put Cooperative Bank at the top of a pyramid of thousands of cooperative societies, most of which have ceased functioning. Cooperative Bank is emerging as a dynamic bank, becoming the first to issue a cash card (a prepaid travel card issued in collaboration with MasterCard, intended for Myanmar residents traveling abroad). It has the largest ATM network of all the country's banks (Mahtani 2013).

- Global Treasure Bank is owned by government-organized livestock and fisheries associations, but its loans cover a wide range of sectors. The bank, which was formerly known as Myanmar Livestock and Fisheries Development Bank, has 60 branches nationally and has offered money remittances into Myanmar through Western Union since January 2013.

- The other semigovernment banks are mostly city-based banks that partly operate as treasuries for local governments and municipalities. They include Yangon City Bank, backed by the Yangon City Development Committee of the municipal authorities in Yangon; Innwa Bank, owned by the Myanmar Economic Corporation, run and owned by current and former military officers; Yadanabon Bank, with just one branch; and Rural Development Bank (previously known as Sibin Thayer Bank), which mainly operates in border areas and is controlled by the central government.

The 10 remaining private banks are genuine private banks. These are:

- $\quad$ KBZ Bank (KBZ is short for Kanbawza) is the largest private bank with 100 branches (as of March 2013). It recently opened an insurance company, IKBZ. Started in Shan State in 1994, 
KBZ Bank is part of the Myanmar Billion Group, which has holdings in a variety of industries, including mining, trading, distribution, manufacturing, and, most recently, airlines (after the bank bought an 80\% holding in Myanmar Airways International in 2010 and launched its own airline, Air KBZ, in 2011). KBZ Bank is rapidly modernizing, extending its widespread domestic remittance services to overseas customers, providing credit card and ATM services, and improving service standards. Although it was the object of a bank-run triggered by social media in 2012, it emerged relatively unscathed and observers now consider it among the most efficient and rapidly growing banks in Myanmar.

- First Private Bank, set up in 1992, was the first genuinely privately owned bank, and it has become one of the most profitable and dynamic private banks in the country.

- Yoma Bank was the second largest private bank in 2003, but following the banking crisis of that year, had to resort to emergency financing from the CBM and consequently had its operations restricted to remittance transfers only. Officials removed those restrictions in 2012, allowing Yoma Bank to resume normal operations. It is now in the process of filling its loan book and should soon be an important competitor in the private banking system.

- Asia Green Development Bank was one of four "crony banks" hastily given a banking license just before the military handed over power to a civilian government in 2010. The other three are Ayeyarwady Bank, United Amara Bank, and Myanmar Apex Bank. Asia Green Development Bank has rapidly grown into one of Myanmar's most important private banks and is part of the Htoo Group, possibly Myanmar's largest conglomerate, which is owned by Tay Za (arguably Myanmar's richest businessmen and possibly its most politically influential one). The US Treasury had previously sanctioned Tay Za, who it called a "notorious henchman and arms dealer." In 2013, however, the US Treasury issued a general license to the bank, one of four Myanmar banks allowed to transact business with US companies (the others are Myanmar Economic Bank, Myanma Investment and Commercial Bank, and Ayeyarwady Bank).

- Ayeyarwady Bank is owned by U Zaw Zaw and is part of the Max Myanmar Group. The bank was a target of US sanctions, but since 2013 , it has been allowed to transact business with US companies. It has 48 branches and is growing rapidly.

- United Amara Bank is owned by Nay Aung as part of the IGE (originally International Group of Entrepreneurs) conglomerate, which has interests in oil and gas, petrol retailing, banking, agriculture, timber, and other sectors.

- Myanmar Apex Bank is owned by Chit Khaing and is part of the Eden Group. The bank has 20 branches and is rapidly modernizing its operations.

- Myanmar Oriental Bank, established in 1993, is owned and operated by and for the Chinese community in Myanmar. Although not among the largest private banks, it is one of the most transparent, regularly publishing its financial statements, reflecting its professional management and its desire to eventually become a joint venture with a foreign bank.

- The Tun Foundation Bank is an unusual financial institution, which devotes its net after-tax income to health and education charities. While not at the forefront of growth and efficiency among private banks in Myanmar, it is nevertheless a respected institution that seeks to ensure that its operations are within the letter and the spirit of the law. 
- The Asia Yangon Bank is a small bank specializing in wholesale banking, servicing large corporate clients, midsized companies, real estate developers, and investors.

A large number of licensed, small microfinance institutions serve small borrowers. These are not banks per se, although many have a license to collect deposits (See Section VII.C.3 for a detailed discussion on microfinance). In the formal sector, Microfinance Bank, established in July 2013, is currently putting its financing arrangements in place. Supported by the IFC with a $\$ 2$ million loan, it was set up by Cambodia's ACLEDA Bank, which has an excellent microfinance track record in that country.

Two bank license applications are before the CBM awaiting approval. Construction and Housing Development Bank has the support of the Ministry of Construction, but its share capital has yet to be funded. The other bank is for livestock development (Elevenmyanmar.com 2013).

Myanmar does not yet permit FDI in banking. There are currently 28 representative offices of foreign banks in Yangon, which provide liaison support to clients operating in the country. Perhaps the most visible is Standard Chartered, which, in an agreement signed between President Thein Sein and the United Kingdom's minister of trade and investment, will work with the British authorities to develop capacity in Myanmar's finance sector through education, training, and technology development (Thuya 2013).

There are very few formal nonbank financial institutions. The Ministry of Finance's Insurance Business Supervisory Board regulates the insurance industry, but state-owned Myanma Insurance, Myanmar's only formal insurance company until 2013, performs the board's work, including the regulatory oversight of the sector. The board granted domestic operators 12 new licenses in 2013 (to provide a range of services similar to Myanma Insurance). These were Aung Myint Mo Min Insurance, Aung Thitsar Oo Insurance, Ayeyar Myanmar Insurance, Capital Life Insurance Application, Citizen Business Insurance Company, Excellent Fortune Insurance Company, First National Insurance, Global World Insurance, Grand Guardian Insurance, IKBZ Insurance, Pillar of Truth Insurance, and Yang Insurance Global. Eleven of them have already started operations.

Myanmar has a nascent capital market. An estimated 60-70 private companies that operate in the country have shares issued to the public and permit over-the-counter trading in their shares. Shareholders can visit a company's offices to buy or sell shares or receive company performance updates. The law permits only Myanmar citizens to buy or sell shares. None of these companies, however, use the Myanmar Securities Exchange Center, which was established in 1996 as a joint venture between Myanmar Economic Bank and Japan's Daiwa Institute of Research. So far, the exchange lists only two companies: Myanmar Citizen's Bank and the Forest Products Joint Venture Corporation. Both are semigovernment institutions (the latter is the commercial arm of the Ministry of Environmental Conservation and Forestry), and there is virtually no trading in their shares. In 2012, the Tokyo Stock Exchange Group and Daiwa Securities Group were chosen to help Myanmar set up a stock exchange by 2015.

\section{FINANCIAL SYSTEM PERFORMANCE}

Every indication suggests that Myanmar's finance sector has been growing rapidly, such as the number of branches and ATMs, or the amount of deposits, loans, foreign exchange transactions, fund transfers, and remittances. Unfortunately, it is difficult to be precise about the rate of expansion because of the 
scarcity of relevant data. Although banks do indeed submit data daily, weekly, monthly, quarterly, and annually to the CBM, this information is not publicly available. Even so, it is clear that the genuinely private banks are the most dynamic participants in the financial system, with the result that the 22 private and semigovernment banks together have recently outstripped the four state banks in terms of total financial assets.

This rapid growth, however, is from a small base. Myanmar's formal financial system is small by most international standards, including bank assets as a share of GDP, number of bank branches per 100,000 people, number of bank loans per 1,000 people (Figures 2 to 4). Decades of state ownership and policy shocks imposed on the system have contributed to a lack of confidence in cash as a safe asset, and in banks as institutions capable of protecting financial assets. Rural areas have limited access to banking services, and bank lending to agriculture is largely restricted to the Myanma Agricultural Development Bank, which covers only a small share of the financing needs of farmers (KloeppingerTodd and Sandar 2013).

Figure 2: Commercial Bank Branches in Low-Income Countries, 2012 (per 100,000 adults)

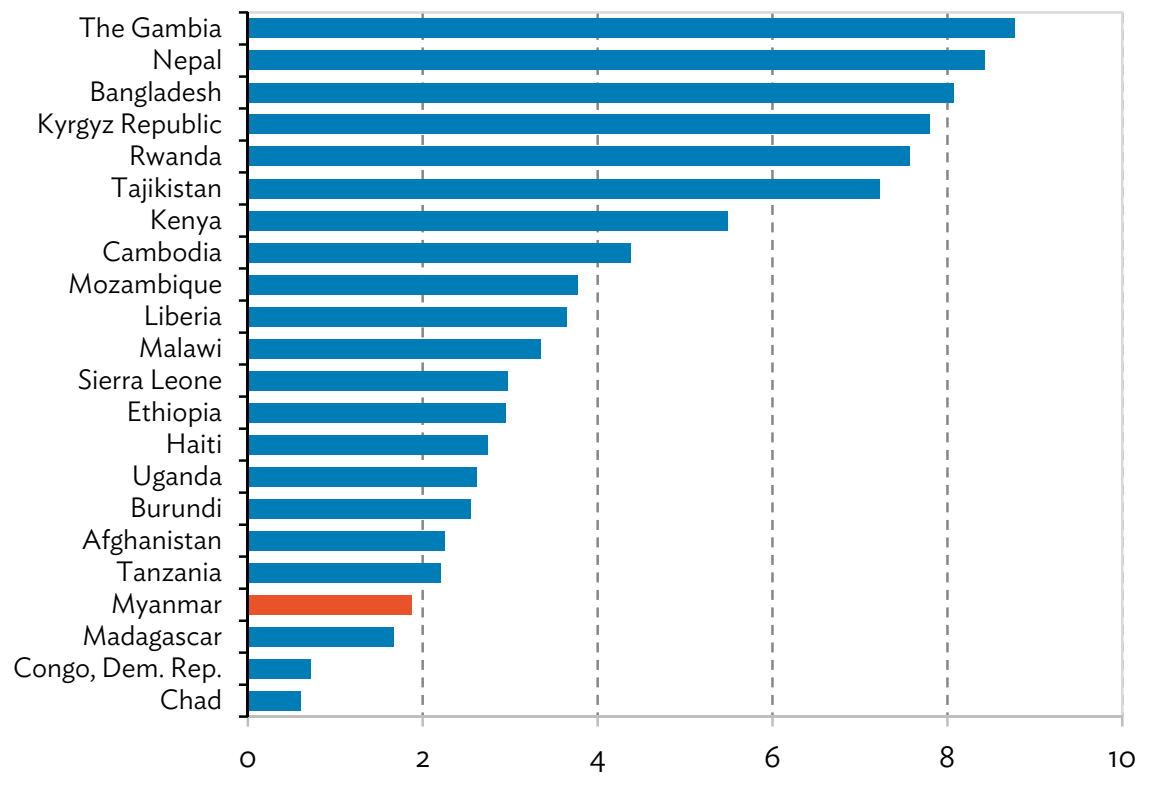

Source: World Bank. World Development Indicators. http://data.worldbank.org (accessed June 2014). 


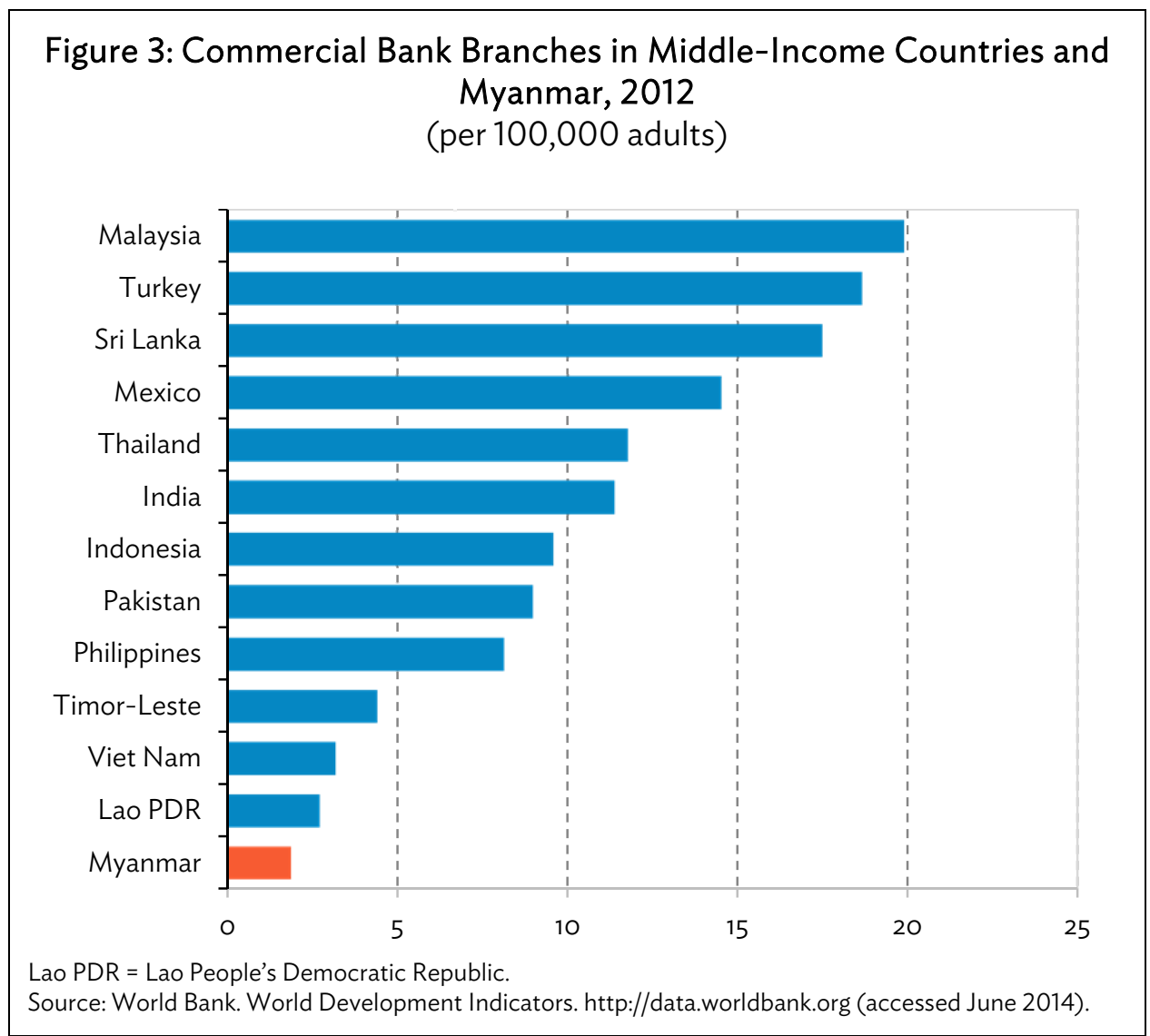

Figure 4: Borrowers from Commercial Banks in Low-income Countries, 2012 (per 1,000 adults)

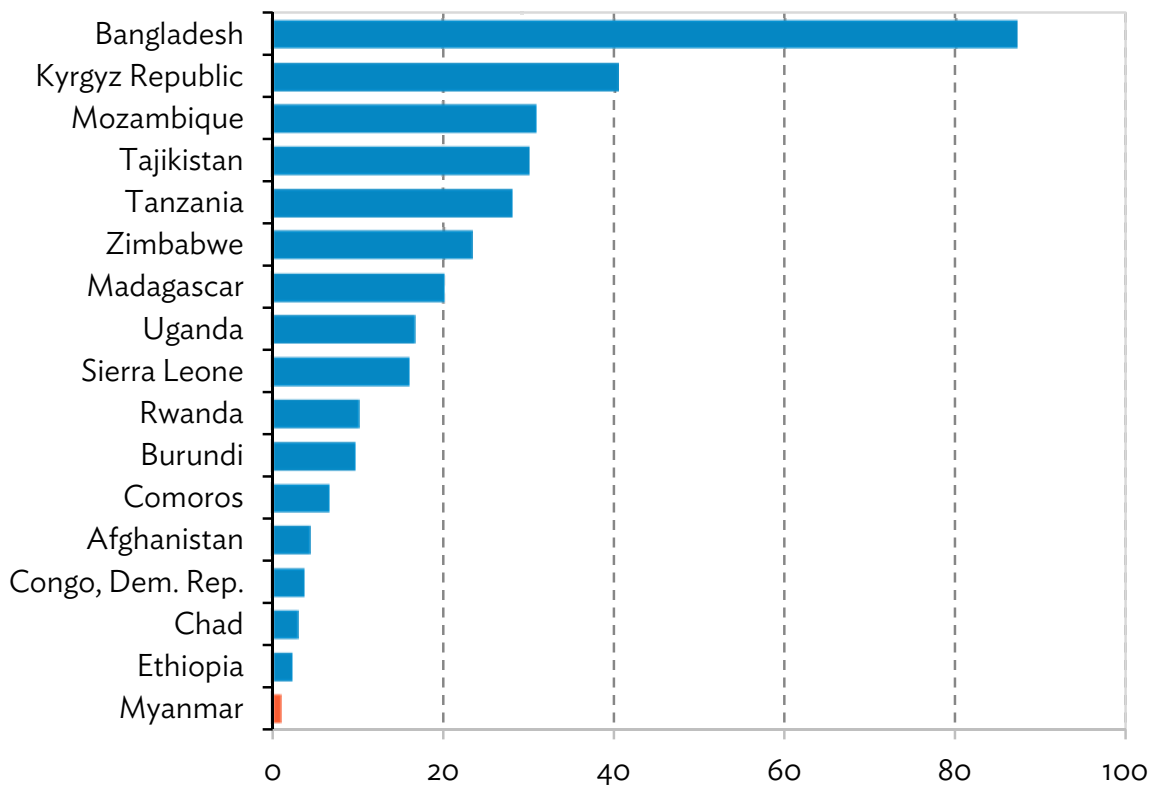

Source: World Bank. World Development Indicators. http://data.worldbank.org (accessed June 2014). 
Collateral-based lending, and the predominance of land as the preferred collateral of choice, inevitably restrict lending to those with land holdings and exclude all others. Recently, however, the authorities expanded collateral options to include key agricultural export goods. Here, private banks manage risks by adjusting the loan value to the estimated value of the collateral. This ratio can be as low as 30\%, although most banks use $50 \%$, and in cases where the borrower is considered particularly creditworthy, the ratio can be higher. In the event of default, banks have successfully taken defaulters to court to acquire the collateral, but some banks require a presigned deed of sale of the collateral, which can then be redeemed in the event of default (although this also requires court approval).

State banks are encumbered by social responsibilities imposed by the state, and dynamic private banks are rapidly eroding their market share of lending to businesses. Indeed, despite privileged treatment by the authorities - for example, interest income on deposits with state banks is nontaxable and state banks are not subject to CBM oversight-state banks are unable to compete with their private sector competitors. Furthermore, state banks have little incentive to manage risk, in part because their lending is largely at the direction of government, but also because government guarantees ensure that banks will be recapitalized in the event of insolvency.

Private banks also have shortcomings. Closely integrated private commercial groups own most and, consequently, their loan portfolios tend to be concentrated within the group, which can mask large risks. The CBM faces considerable challenges in implementing regulations that restrict relatedparty lending, which include a 20\% single borrower limit and a 20\% related-party borrower limit. In addition, borrowers who do not belong to bank-owning conglomerates-especially micro-, small-, and medium-sized enterprises - find it difficult to access finance from the formal banking system and must resort to borrowing from informal sources, where loans are usually at higher interest rates and shorter maturities.

Growth of the financial system, in general, and the banking system in particular, is constrained by weaknesses in basic institutional systems and infrastructure. The financial system, especially, needs an automated payments clearance system, a money market system for modern liquidity management, and an electronic real-time data system connecting banks with the CBM. Payments are predominately cash-based and often involve the physical movement of large amounts of cash across the country. Progress on an interbank payments system has begun, but check clearing between banks is still manual and the system for real time gross settlement is still in its planning stage.

An informal and unregulated payments network predates the banking system by some 30 years. Under the so-called Hundi system, dealers facilitate payments through business or family networks, primarily between Myanmar and the rest of the world (Turnell 2009).

There is no credit information system and the CBM is only just developing its offsite and onsite supervision capabilities. The reporting systems of the banks and the CBM use fax, with no online, realtime link. The CBM's capacity to analyze and digest this data is limited, and none of this information is made public. The absence of well-functioning institutional infrastructure and information systems limits financial development; constrains the CBM's ability to monitor, analyze, and supervise the banking system; and impedes banks' liquidity and cash management. The lack of debtor information also leads banks to base their lending on collateral and guarantees, and limits lending to small borrowers. 


\section{RECENT AND ONGOING REFORMS}

The government has made considerable progress in quite a short period in implementing reforms that will have a significant effect on finance sector development. These include policy changes affecting the financial system directly, as well as those affecting the system indirectly. The most significant example of the latter is the liberalization of the foreign exchange market. A daily foreign exchange auction is held and the official exchange rate has now converged to the "kerb market" rate. The generally free availability of foreign exchange has increased business opportunities for banks, as it has for the entire economy. Since October 2011, the CBM has granted licenses to private banks for the operation of foreign exchange counters, and since November 2011 for foreign exchange dealer licenses (including an interbank foreign exchange market and currency remittance services for Myanmar citizens living abroad). A new FDI law was approved in 2012, and accompanying rules and regulations have been issued. The law provides a conducive legal framework for all foreign investment in the country, including in the banking system, for example, by protecting foreign investors from the nationalization of their assets during the life of a project, and through any extension period approved by the Myanmar Investment Commission.

In addition, the government has approved important new laws that will contribute to the country's financial infrastructure. In July 2013, Myanmar's President approved the Central Bank Law, which repeals the Central Bank of Myanmar Law of 1990. However, the rules, regulations, by-laws, orders, and directives issued under the repealed law remain in force until a new body of associated regulations is issued. The main feature of the new law is that the CBM is an autonomous body independent of the Ministry of Finance. Once the associated regulations are issued, the central bank will have two main objectives. The first is to promote efficient payment mechanisms, and ensure liquidity, solvency, and proper functioning of the financial system. The second is to foster monetary, credit, and financial conditions conducive to sustainable economic development.

In the furtherance of these objectives, the CBM will be able to independently adjust interest rates and conduct currency and exchange operations. It will be responsible for the supervision of banks only-nonbank financial institutions and microfinance institutions remain under the supervisory authority of the Ministry of Finance.

A nine-member governance board has been established, chaired by a newly appointed central bank governor. The President's office must nominate board members, and parliament approves them. The newly independent central bank also plans to double staff and set up new departments. There will be committees in charge of financial stability, monetary policy, payment systems, and foreignexchange management.

The Central Bank Law of 2013 and its accompanying regulations will allow the CBM to revise its earlier practice of implementing prudential regulations through direct interventions-which often required ex-ante approvals-and replace them with indirect approaches, such as onsite and offsite supervision, real-time electronic data transfer, and ex-post penalties against violations of central bank requirements. The new central bank regulations will need to end the earlier practice of discriminating against private banks and providing financial support and regulatory forbearance in favor of state banks. For example, capital-deposit ratios are currently applied only to private banks, not state banks. Deposit interest income from state banks is tax-free, and they are not required to report their financials as often as private banks. Private banks are effectively locked out from lending to agriculture, because state-owned Myanma Agricultural Development Bank operates as an agency of the Ministry of Agriculture and bundles inputs provided by state enterprises (for example, seeds and fertilizer) and financing, and the ministry buys the final agricultural product. 
A new Securities Exchange Law enacted in July 2013 provides the framework for the establishment of a stock exchange. The law establishes a securities and exchange commission to supervise the securities market. It lists the licenses needed for businesses dealing in securities (brokerages, underwriters, investment advisors, and company representatives), allows the establishment of an over-the-counter market, lists actions in violation of the Securities Exchange Law (such as insider trading) and prescribes penalties, and provides for setting up a securities depository and clearing agency. A new company law now needs to accompany the Securities Exchange Law, to provide for improved corporate governance and accountancy standards, a robust regulatory and reporting framework, and a level of transparency that will give domestic and international investors adequate information for investment decisions.

A revised Financial Institutions Law is being drafted with the assistance of the World Bank to replace the current 1990 law. The law is expected to set out the licensing requirements for private banks, corporate governance arrangements, and the conditions for foreign investor participation in banking in Myanmar.

Because of these and other reform initiatives, an overall policy framework for the banking system is gradually taking shape and is broadly consistent with international norms and practices. Increasingly, the challenge will not be the regulatory framework itself, but the capacity of government institutions, especially the central bank, to implement these laws and regulations and ensure that all banks, state and private, follow them in spirit and to the letter. Private banks have already been given greater freedom to set up branches, buy and sell foreign exchange, hold foreign exchange assets on their balance sheets, and, in some cases, even lend indirectly to the agriculture sector. These freedoms appear to be piecemeal and not only need to be enshrined in new regulations, but applied to all banks equally.

Other central bank policies and regulations governing bank operations may change from time to time depending on circumstances and requirements, and include the following:

i. A $10 \%$ risk-weighted capital-adequacy ratio, which is reasonably cautious, although the definitions of bank capital, risk weightings, and nonperforming loans are not yet based on international standards.

ii. A maximum loan-to-deposit ratio of $80 \%$, applicable only to private sector banks, had been in effect, but was recently abolished.

iii. A cap on deposits equivalent to 10 times paid-up capital; this was initially set at seven times following the 2003 crisis and relaxed to 10 times in 2006.

iv. A single-borrower limit and a single related-party lending limit set at $20 \%$ of a bank's capital base.

v. A reserve-requirement ratio equivalent to $10 \%$ of total deposits.

vi. A minimum liquidity ratio equivalent to $20 \%$ of deposits (in addition to the $10 \%$ required reserve requirement with the $\mathrm{CBM}$ ).

vii. Maintenance of a general reserve account equal to paid-up capital, to be funded by $25 \%$ retention of net profits (until the requirement is met).

viii. General provisioning of $2 \%$ of total loans and loan-loss provisioning equal to $50 \%$ and $100 \%$ of doubtful and bad loans, respectively.

ix. Loan maturities of more than 1 year are not permitted, but borrowers may roll loans over for a further 2 years.

x. Collateral is required for all lending; this can be property (land and building), gold, and, recently added, key agricultural export commodities. 
xi. The CBM regulates interest rates for deposits and lending. Current lending, deposit, and central bank rates are set at $13 \%, 8 \%$, and $10 \%$, respectively. CBM regulations actually permit banks to set deposit rates within a range around prescribed levels, but complaints by smaller private banks unable to compete against larger, more modern ones led to "informal" CBM instructions that any variation around the central rates would not be countenanced.

Myanmar is making concerted efforts to improve its financial infrastructure. The IMF continues to provide technical assistance for strengthening the CBM's capacity (two resident advisors with the CBM will assist foreign exchange market development and bank supervision). It will also help in reorganizing the Ministry of Finance now that it has the task of reabsorbing all treasury functions the banking system is currently conducting (IMF 2013a). The World Bank and IMF are helping prepare a finance sector development master plan that includes a finance sector development strategy. JICA is helping develop a CBM electronic network and a clearance and payments settlement system, and the Tokyo Stock Exchange and Daiwa Institute of Research have been tasked with the development of the stock exchange. Myanmar is also receiving technical assistance support from the Japan-ASEAN Technical Assistance Fund to enhance the development of a bond market.

A Myanmar Payment Union has been established with 16 of the 22 private banks as members, with a small number of retailers also in the system. The payment union is already offering a network of ATMs that permit the withdrawal of cash for customers of participating banks. The plan is for it to link with international card networks, such as VISA, MasterCard, the Japan Credit Bureau, and China Union Pay, all of which have signed agreements with local banks. The CBM, for the first time, has approved the issuance of a prepaid, internationally accepted debit card by a semi-official private bank, Cooperative Bank, which is collaborating with MasterCard. Other banks have also applied for introducing similar prepaid debit card services.

The newly established Myanmar Microfinance Supervisory Enterprise is authorized to issue licenses to new microfinance companies-domestic or foreign. It has so far issued 166 licenses, of which 50 are licensed to issue credit as well as accept deposits from the public (effectively making them banks). According to the IFC, Myanmar has about 2.8 million microfinance clients, with total loans outstanding of about $\$ 242$ million. The Myanma Agricultural Development Bank has the largest domestic microfinance loan portfolio (\$86 million). The United Nations Development Program's microfinance arm, PACT, is the largest nongovernment organization in the microfinance sector (\$29.5 million). Only three foreign microfinance companies have been given a license to operate in Myanmar, including Acleda Bank of Cambodia, which started operations in partnership with the IFC. A number of nongovernment organizations operate microfinance projects; one of them, Proximity Designs, has received a $\$ 2$ million grant from the Government of Norway to expand operations. Some international nongovernment organizations operating microfinance projects, among them World Vision, are considering applying for a commercial license so they can receive equity investments from domestic and international partners to expand their loan portfolios.

\section{NEED FOR A FINANCE SECTOR STRATEGY}

Myanmar's finance sector has made big strides in the past 2 years and many reform initiatives are under way. It is important to maintain the momentum. The focus will need to be the rapid development of the sector while ensuring stability, efficiency, and increasing access to financial services. 
To achieve this objective, the government will need to prepare a finance sector development strategy, using as a starting point the master plan being prepared with the help of the IMF and the World Bank. Stakeholders, the finance sector, and the public should thoroughly discuss and understand the strategy. It will eventually need to have the full support of the government and the country's highest leadership, and should receive broad-based, nonpartisan support from parliament and other stakeholders.

The finance sector development strategy should begin with a feasible and ambitious vision of the finance sector by, say, 2030. This should be the reference point for all government policies and programs aimed at the development of the sector. It should also be consistent with and support the country's broader development goals.

By 2030, Myanmar should have a stable, strong, competitive, and inclusive financial system that provides access to financial services to the entire population (compared to 10\% today), and contributes to growth by channeling domestic and foreign savings effectively and efficiently toward productive investments throughout the economy. Indonesia, Malaysia, and Thailand offer good examples of the way forward.

At the core of the financial system should be a few large and strong domestic private banks that employ economies of scale and scope to maintain low intermediation margins, provide a range of financial services efficiently and effectively, extend loans of different maturities, and, having built their capital base, can compete successfully against foreign-owned banks in the domestic market.

Financial services will be available to all through a healthy set of microfinance institutions and one or two large, independent, well-financed, and professionally managed development banks (or credit guarantee agencies). The domestic credit-to-GDP ratio should have reached around 50\% (around India's current level and higher than Indonesia's 35\%). The CBM should focus on growth and price stability as twin objectives, ensure systemic stability and smooth functioning of a competitive banking system, and employ market-friendly instruments to conduct monetary policy. The nonbank finance sector should be managed by specialized regulatory institutions, and include domestic private companies (most domestic and a few foreign) in diverse areas such as insurance, hire-purchase, pension fund management, and microfinance. The capital market should be a growing source of risk equity and bond finance, and the stock market should aim for a capitalization-to-GDP ratio of around $50 \%$ (lower than India's but higher than Indonesia's ratio today) although it would still be small in relation to the banking system.

Achieving this vision will first require a finance sector strategy to chart out the needed steps to the desired goals in 2030. Properly sequencing reforms will be critical to avoid crises or missteps. The strategy should also minimize the burden on Myanmar's limited administrative capabilities and focus on overcoming constraints that "bind" the sector's development.

Alleviating capacity constraints in the finance sector-whether in the central bank or in the private sector-will be one of the government's highest priorities when implementing the strategy. Training will be important, but not enough; policy makers must also consider other innovative approaches to overcome capacity bottlenecks, including technology and skills from abroad to complement the domestic contingent. Of equal importance, implementing a financial strategy requires coordinating the many different parts of government and needs guiding by policy makers at the highest level of government. Periodic evaluation of the progress of implementation and needed adjustments are also important. 
The central bank governor will need to lead implementation of most banking system reforms, which is why central bank independence and proper implementation of the new Central Bank Law are so important. The CBM also needs sufficient skilled staff and strong leadership to provide an institution with a solid knowledge base and experience in banking, finance, central bank operations, and macroeconomic policy that has the confidence of the president, as well as the ministers of finance, and of planning and economic development.

Equally important, the government will need to introduce a financial-sector-reform coordination committee at the highest level, led by the central bank governor and the Ministry of Finance, to monitor reform strategy progress and to make necessary adjustments. The committee should also be responsible for coordinating donors providing support to the finance sector and make sure the donor community supports Myanmar's priorities and avoid diverting attention to low-priority activities.

\section{KEY COMPONENTS OF A FORWARD-LOOKING FINANCE SECTOR REFORM STRATEGY}

The following section identifies these key components, building on all initiatives under way. It focuses on three objectives that must underpin the finance sector development strategy: increasing finance sector efficiency, stability, and inclusion.

\section{A. Policies and Measures to Increase Banking System Efficiency}

A financial system's highest priority is to build the strong institutional foundations for the banking system to improve the efficiency, safety, and security of financial transactions. This requires patience, consistent effort, and, perhaps most important, a change in attitude in the government, the central bank, and private commercial banks. Given the scale of the challenge, Myanmar's authorities should tap the international community to help build domestic capacity, with a clear understanding on both sides that, except in very few situations, international expertise should not substitute for the domestic. Instead, it should transfer skills and systems that build domestic capabilities. The priorities in increasing finance sector efficiency include the following:

\section{Automate the Clearance System}

The government has tasked JICA to implement the automation of the CBM clearance and payments settlement system. If approved, JICA will be issuing a request for proposal soon, and the system is expected to be operational by 2015. Clearance for now is manual and, as a result, most transactions are done in cash. As noted, banks spend a lot of time moving large amounts of cash from bank to bank, branch to branch, or to and from the central bank - and considerable time and manpower counting money at each point (which, despite counting machines, is prone to errors). Introducing a clearance system for checks and/or electronic transfers will significantly improve banking efficiency.

\section{Automate the Payments System}

This is also being implemented with the help of JICA, in tandem with the clearance system, and is due to be operational by 2015. The payments settlement system and the clearance system have to be fully consistent to ensure that banks make transfers immediately after checks and/or transfers are cleared. 


\section{Money Market System}

The challenge in the money market system ${ }^{5}$ is the excess deposits in the banking system (Figure 5). Yet the deposit and credit auction system is not working because the budget for it is not adequate. The CBM allows banks to deposit excess liquidity for 14 days at an interest rate capped at $4 \%$, because of budget limitations. This low interest rate gives banks little incentive to use the CBM's deposit facility, especially because they have other ways to use their excess liquidity, including purchasing treasury bonds from the central bank. Next steps include the introduction of market-based monetary instruments (such as central bank bills issued through auctions) that help banks (and eventually nonbank financial institutions) manage their liquidity based on price incentives. The CBM's primary objective should be to encourage banks to trade money and other liquid financial instruments among themselves; only when these prove inadequate should CBM provide funds through its own liquidity facilities. In this regard, repurchase agreements (repos) will be a key instrument and an important method for the central bank to exert indirect monetary control and influence liquidity in the financial system. ${ }^{6}$ Repos become particularly important when counterparty credit risks are high (as they are in Myanmar), in that they are a form of collateralized lending. The repo market, however, requires an underlying legal structure. Participants should meet key prudential financial criteria-such as minimum capital requirements and the ability to meet mandated liquidity ratios-and should be subject to central bank oversight. The CBM should also apply reserve requirements as an initial means to control liquidity, and design a framework by which banks can access the central bank's standing liquidity facilities if their efforts in the interbank market are not successful. The money market will develop as the CBM buys and sells these short-term instruments, adjusts the appropriate level of required reserves in line with macroeconomic needs, and alleviates systemic liquidity shortages when they arise. The IMF and the World Bank are providing technical assistance on all these initiatives.

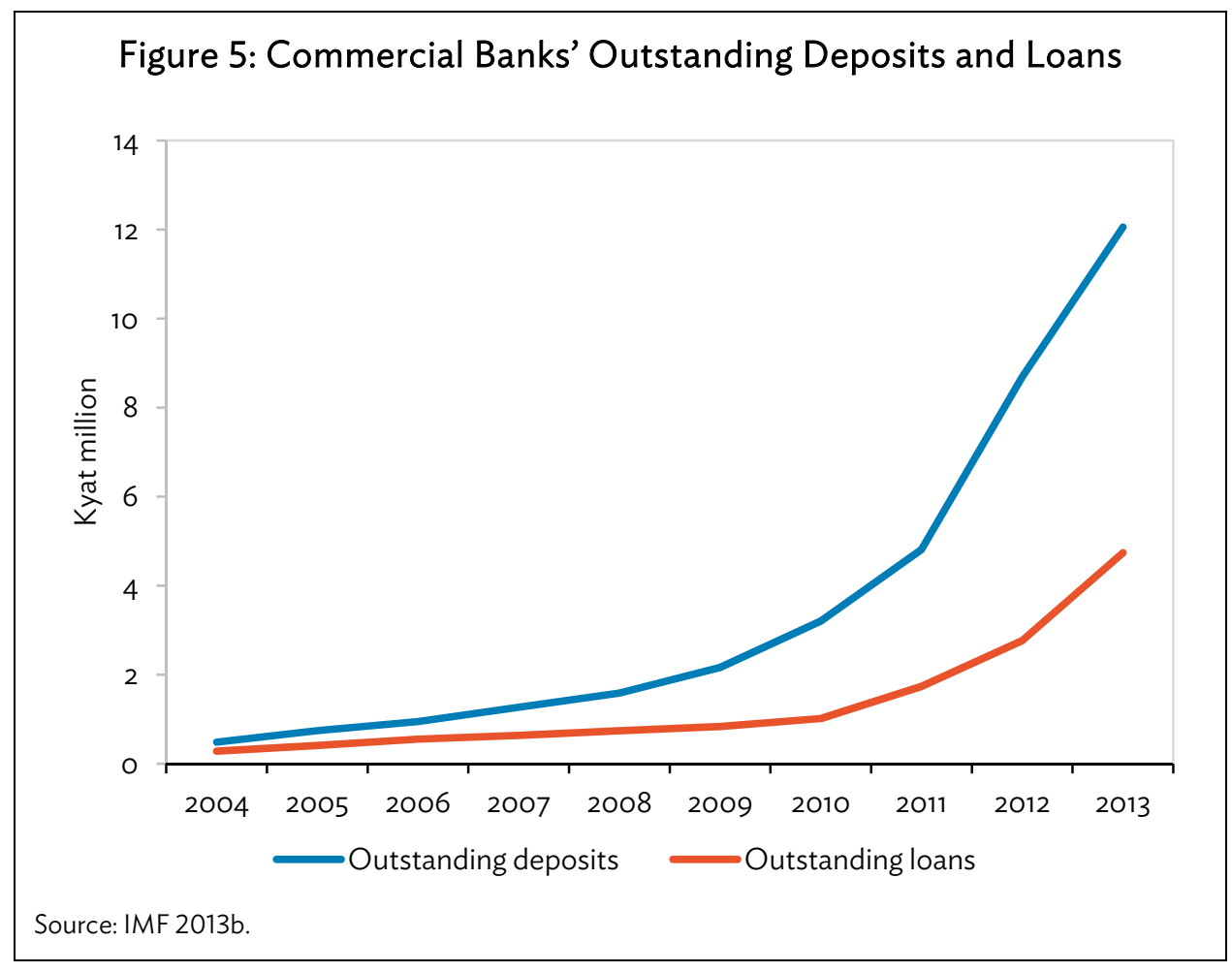

5 For a more detailed discussion, see Nijathaworn et al. (2015).

6 Repos are the sale of securities combined with an agreement for the seller to buy back the securities later at a higher price, with the difference in the sale and the repurchase price creating an implicit interest rate. 


\section{Credit Information System}

Asymmetric information between lenders and borrowers is one of the most important market failures in financial markets. One way to partially correct this is with a credit information system in which all banks have secure access to a smoothly functioning interbank information system that shares accurate and up-to-date data on the outstanding stock of debt of individual debtors, terms of loans, collateral pledged, and repayment records. Myanmar has no such system and has not begun work on one. A modern, credit-based economy requires access to complete, accurate, and reliable information on borrowers' payment histories. Key features of a credit information system include the following:

i. A legal framework. Credit information systems should have legal protection sufficient to encourage their activities without eliminating incentives to maintain high levels of accuracy.

ii. Operations. Measures should be employed to safeguard information contained in the credit information system and incentives should exist to maintain the integrity of the database.

iii. Public policy. The information collected and distributed by credit information systems can be used to advance public policies.

iv. Privacy. Subjects of information in credit information systems should have access to their information and be able to dispute inaccurate or incomplete information, and mechanisms should exist to have such disputes investigated and have errors corrected.

v. Enforcement/supervision. A credit information system could permit regulators to assess an institution's risk exposure, and sanctions for violations of laws regulating credit information systems should be sufficiently stringent to encourage compliance.

\section{Financial Accounting Standards}

The Myanmar Financial Records Standards (MFRS) have already been issued, but they are not enforced, and without this, the CBM's supervision of banks becomes very difficult. It is crucial that all banks and firms use accounting systems that meet the MFRS so that balance sheet, profit-and-loss, and income and expenditure data-as well as all typical financial ratios-are based on the same definitions. Although CBM supervisors analyze the daily, weekly, monthly, and quarterly financials to make sure banks are abiding by the central bank's prudential regulations, the absence of standards makes it difficult to know that the numbers truly reflect the actual condition of the banks. In addition to ensuring that all banks use the MFRS, it is important that the CBM require all banks to publish their audited balance sheets and income statements, post them on bank websites, and issue them in printed form for the public, stakeholders, and relevant parties. The 1990 Financial Institutions Law does not require this, an oversight the new Financial Institutions Bill needs to correct. With real-time, electronic access to commercial banks accounts (which should be part of the JICA-supported clearance and payments settlement system), CBM supervisors can better analyze the actual submitted data for a better understanding of banks' financial positions, the riskiness of their portfolios, and their solvency and liquidity. Introducing MFRS in corporate accounts would also significantly improve the ability of commercial banks to assess their credit risks.

\section{Enhance the Role of Foreign Direct Investment in Deliberate Steps}

Foreign banks can now only run representative offices, while the financial institutions law forbids foreign investment in domestic banks. Virtually all foreign investors and traders use foreign banks based abroad to finance their operations in Myanmar. While this could continue, it obviously limits and impedes foreign investments in Myanmar and prevents state-of-the-art financial services from entering the financial system and benefiting households and firms. Debate is ongoing whether and how foreign banks can gradually enter the banking system. The authorities are considering various 
possibilities, including strategic partnerships, joint ventures, and, finally, full ownership. Many private banks are keen to enter into partnerships or joint ventures with foreign banks to get access to new technology, training, finance, external retail branching networks, and better management.

Authorities should base their decisions on the role of FDI in the banking system and a clear understanding of its advantages for the finance sector and the systemic finance sector risks that the immediate entry of foreign banks could induce. International evidence shows that FDI in the banking sector can offer important benefits, but that it can indeed introduce risks (Claessens, Demirgüç-Kunt, and Huizinga 2001). Foreign banks can help build a more robust and efficient banking system by introducing international practices and standards; by enhancing the quality, efficiency and breadth of financial services; and by accessing more stable sources of funds. These benefits could be substantial, provided the regulatory and institutional framework for the financial system is strong. But if it is weak, the benefits and costs of FDI depend on how it is phased in and what other reforms, particularly in the regulatory and institutional framework, accompany it. Countries with successful experiences opened up to foreign banking only after they already had well-developed institutional capacity and they were already engaging in rapid domestic deregulation. Successful examples are mainly of middle-income and advanced economies such as Argentina, Spain, Ireland, and Portugal. There are no examples, however, of low-income countries that opened the banking sector successfully to FDI without numerous restrictions and limits.

It follows that the Myanmar authorities for the time being may wish to err on the side of caution when considering the entry of foreign banks. The institutional infrastructure and regulatory framework for banking remain weak and will take years to strengthen. The premature entry of foreign banks could lead to a rapid shift in the depositor base from domestic banks to the new foreign bank entrants, placing domestic banks at risk of financial distress and possibly placing the solvency of the entire domestic financial system at risk as well.

That does not mean, however, that FDI in banking should not be encouraged at all. On the contrary, the authorities should encourage domestic banks to pursue strategic partnerships and joint ventures with foreign banks. Some of these cases may involve accepting foreign share capital in an existing domestic bank. In others cases, a joint-venture bank could be established anew (although the government would need to take care that the number of new banks be kept in check (See Consolidate the Number of Commercial Banks on page 27).

It is possible that in the first few years no foreign banks will be eager to assume the role of minority shareholder in a Myanmar bank. This should not discourage the government. With further stabilization and reform of the banking system along the lines suggested in this paper, foreign interest in joint ventures will pick up.

In the meantime, the government, with support of bilateral donors, as well as the World Bank and $A D B$, should contract foreign banks to provide technical assistance and training to Myanmar bank personnel and management. In subsequent years, when the authorities are convinced that the regulatory and institutional framework is in place and domestic banks are financially sound, they may consider licensing majority foreign-owned bank operations in Myanmar. If, on the other hand (and against the recommendations contained in this paper), the authorities allow full foreign ownership immediately, then they would be prudent to impose a ceiling on the market share that foreign banks can acquire to prevent the emergence of systemic risks in domestic banks. 


\section{Interest Rate Policy}

Currently, interest rates are fixed (Figure 6) $-10 \%$ is the central bank reference rate at which banks can borrow from the central bank. Deposit rates are set 2 percentage points below (8\%) and lending rates 3\% above (13\%). Treasury bond rates are also linked to the reference rate- $8.5 \%$ for 2 years, $9.0 \%$ for 3 years, and $9.5 \%$ for 5 years. While CBM regulations allow banks to compete within a narrow band around these interest rates, in reality the CBM requires strict adherence to the actual rates (banks are expected to compete on service standards, not interest rates). The fixed interest rate structure has meant that real interest rates have been very volatile, given the variance in inflation rates (Figure 7). The fixed interest rate structure also permits banks to use their excess liquidity to purchase treasury bonds, but liquidity shortages are somewhat more difficult to manage in the absence of a secondary market.

In finance sector reform priorities, it is best that the CBM does not initially change its approach to a fixed interest rate structure (it should adjust this structure from time to time to reflect macroeconomic conditions and monetary policy objectives), but focus instead on building the financial system's infrastructure, including its own supervision system. Liberalizing interest rates too early in the absence of a strong financial infrastructure and supervision and risk management system can lead to risky bank behavior and exacerbate systemic risks. The appropriate sequence should be the following:

i. First, stick to the CBM establishing the interest rate structure as it is doing now, but ensure that depositors earn positive real returns on deposits and banks have an adequate intermediation margin.

ii. Second, after some years and the development of CBM capacity and suitably strong financial infrastructure, the central bank could consider replacing the fixed interest rate structure with a floor for lending rates and a ceiling for interest rates. As noted in the introduction, this will gradually introduce some competition among banks on the price of capital (at the margin).

iii. Finally, after what could be more than a decade or two of strong finance sector development, the government could consider liberalizing lending rates first, and later liberalizing deposit rates. This last stage is not something that should concern policy makers now.

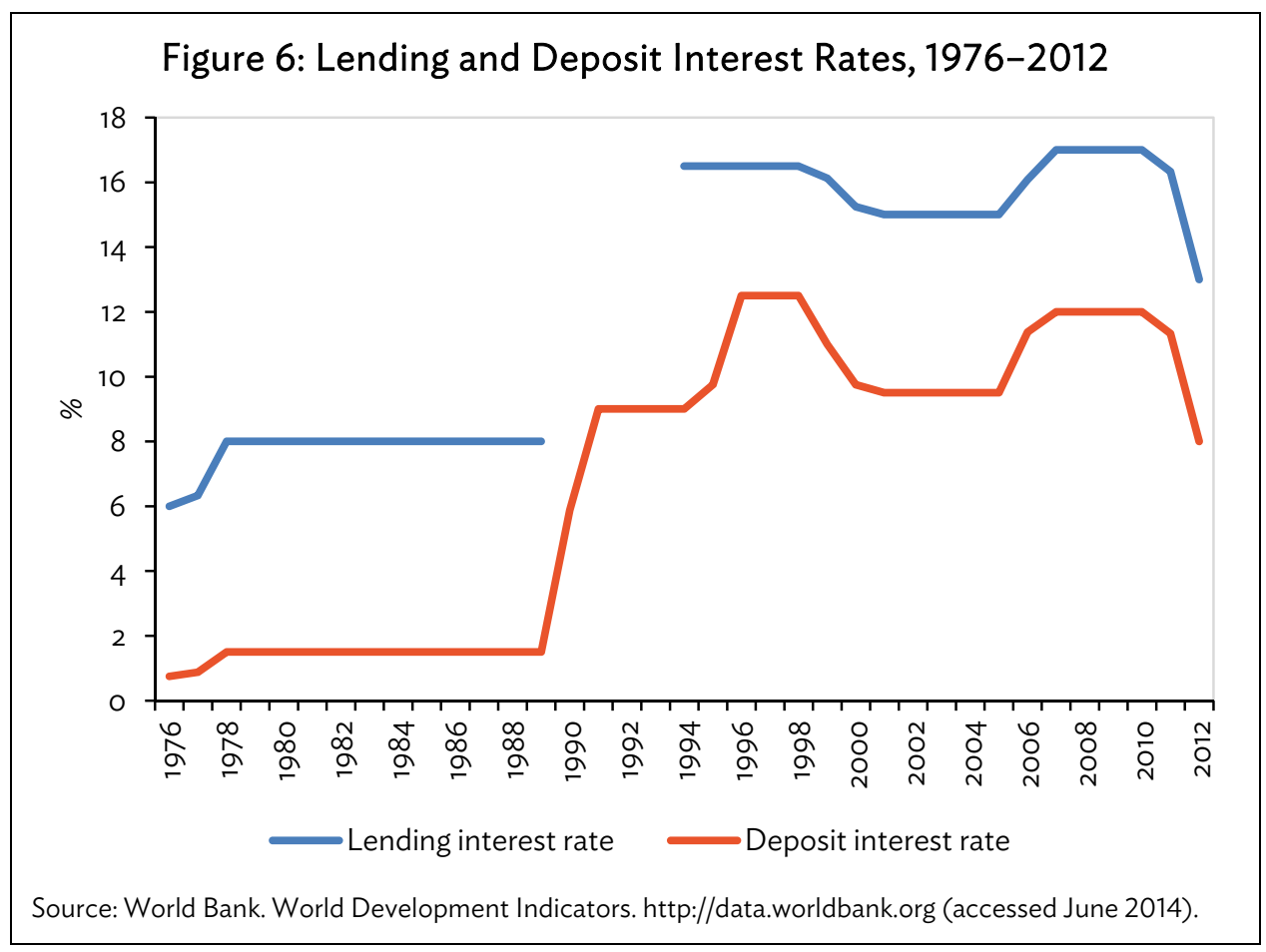




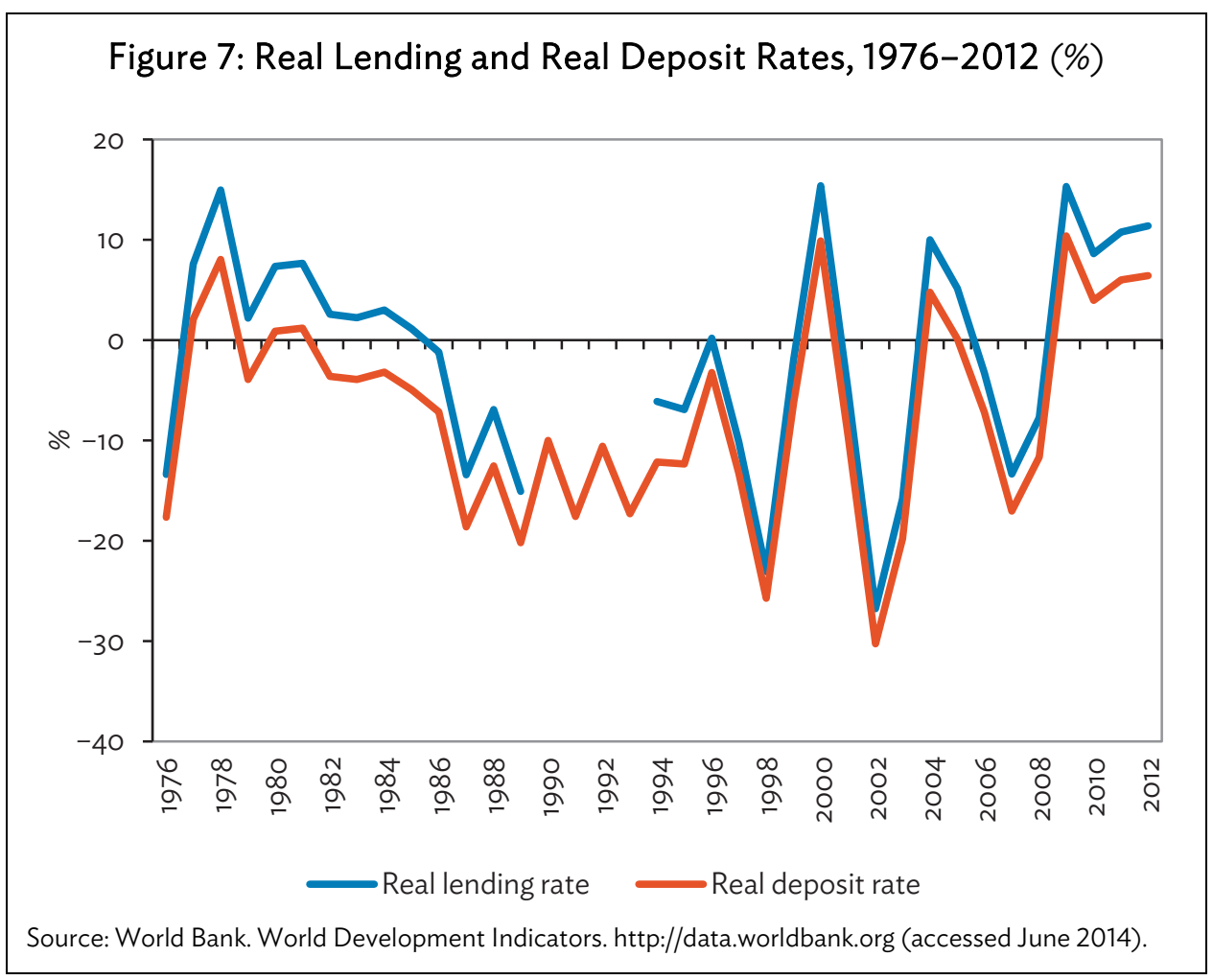

\section{Consolidate the Number of Commercial Banks}

Myanmar's commercial banking system has 24 banks, including the Microfinance Bank established recently, and could add a Construction and Housing Development Bank and a Livestock Development Bank. Are more banks better than fewer? Research in many countries suggests that authorities need to balance the increased competition that comes from having more banks in a financial system with the economies of scale that come with larger banks and the franchise value of banks that can affect their approach to risk taking. If franchise values decline too much, banks can become risk prone just to survive in a highly competitive environment, generating systemic risks (Caprio 2010). ${ }^{7}$ In this sense, the finance sector is very different from other services and goods sectors. So, for now, Myanmar's commercial bank contingent appears more than ample. Not only would it make little sense to allow more bank entrants at this stage, it would be appropriate for the authorities to encourage mergers between banks to reduce the number, starting with the state banks (See Restructure State Banks on page 28).

\section{Apply Regulations Equally to State and Private Banks}

As noted earlier, with weak central bank oversight and supervision, it would be inappropriate to allow banks to compete for deposits and borrowers on interest rates. Not allowing them will avoid excessive risk-taking and lower the probability of bank failures. At the same time, however, banks must be allowed to compete based on service standards and fees. An important component of bank income accrues from fees for remittances, whether domestically or internationally. The CBM has fixed the remittance fee at $0.125 \%$ of the transfer amount-but such fees could be subject to competition

$7 \quad$ Also, see Agoraki, Delis, and Pasiouras 2009. 
between banks. Similarly, to encourage bank competition, the CBM and the government should ensure that rules under the Financial Institutions Law are applied equally to state banks and private banks. There is no reason to treat the Myanma Economic Bank, Myanma Foreign Trade Bank, and Myanma Investment and Commercial Bank (MICB) differently when it comes to prudential risk ratios or the tax treatment of income from deposits.

The CBM could also help reduce costs and encourage competition by allowing banks that bid successfully at the foreign exchange auction to indicate an account of their choice to deposit this foreign exchange. At present, the foreign exchange is deposited at the head office account of the private banks - when the money is needed outside the country to pay for import purchases of bank clients. Other similar, low-cost solutions would significantly increase banking system efficiency; the central bank should regularly consult private banks and public representatives (and enterprises) to find them.

\section{Restructure State Banks}

Policy makers need to consider the role of the four state banks in the future banking system carefully. Authorities should return the central banking and treasury functions of these banks to the central bank and the Ministry of Finance in due course, so that the state banks can focus on their banking activities.

In addition, the government could consider two alternative approaches to separating the Agricultural Development Bank from the Ministry of Agriculture. The first would make it a separate and restructured state development bank that would need to be adequately capitalized and focused solely on supporting small-scale agricultural borrowers. Alternatively, it could transfer the responsibilities of the Agricultural Development Bank to the microfinance banking system as well as the remaining private and state banks.

Similarly, the Myanma Foreign Trade Bank (which would need to return the external reserve management functions to the (BM) could transfer its international fund transfer responsibilities to the MICB and allow the MICB to compete with private banks. Now that they have their foreign exchange licenses and are developing their correspondent banking networks abroad, private banks are operating in the same space.

Finally, the Myanma Economic Bank and the MICB should undergo thorough internationalstandard financial audits (again, financed by donor grants). This would thoroughly assess their current financial condition. Based on the results, the authorities should fully capitalize these two banks in accordance with CBM requirements (which should be the same for all banks). They should also change their mandate from commercial banking (which private commercial banks should provide) to development banking. Finally, the CBM should subject them to the same prudential standards and supervision oversight as required for private banks. Good examples of other countries adopting similar reforms are Viet Nam, when it applied ADB resources to audit two state banks before restructuring them, and Indonesia, which used donor resources to finance audits of state and private banks prior to closing or restructuring them.

\section{B. Policies to Promote Financial System Stability}

\section{Strengthening Central Bank of Myanmar Supervision Capacity}

The CBM's bank supervision department has fewer than 20 bank supervisors (split equally between onsite and offsite supervision duties). The CBM needs more supervisors and to train all its supervisors 
in the latest techniques. This will take time, but the demand for high-quality supervision capacity is urgent. The CBM, with the support of grant funding from the donor community, should therefore seriously consider hiring 20 world-class supervisors from neighboring Asian countries, and therefore are familiar with Asian conditions. These supervisors could be contracted for a period of about 5 years to kick-start the CBM's supervision capacity (and the adherence of banks to MFRS), and to train CBM supervisors who can then take over all supervision responsibilities within the 5 years.

\section{Streamlining Regulations}

The thrust of the CBM's reform of its banking regulatory framework will need to be from direct and ex ante oversight and approvals of transactions to indirect and ex post supervision to ensure banks are operating responsibly and within central bank guidelines. More regulations do not necessarily translate to more stability, and could instead smother banking development. Smarter regulation is needed. One approach to achieve this would be to conduct an audit of all banking regulations and eliminate those that serve little purpose-for example, eliminate all restrictions that impede private banks from lending to agriculture, eliminate restrictions to opening new branches (including incremental capital and staffing requirements), and so on. This will be ongoing and could be supported by advisors from international financial institutions and other central banks.

\section{Developing a Risk Management Framework, Including a Resolution Framework and Process for Insolvent Banks}

A key part of ensuring financial system stability is to allow the orderly exit of financial institutions that become insolvent and have little chance of regaining solvency. Authorities should not wait for insolvent institutions to become illiquid and precipitate a systemic crisis, nor should they try to prop up institutions with open-ended financial support (whether from the budget or from the CBM's liquidity facilities), or to curtail competition to protect the viability of certain banks. Instead, the CBM or the Ministry of Finance should consider establishing a department that can assist in the orderly winding down of unviable banks, ensuring that depositors, especially small ones, are protected, and that risks are not transferred to other banks or financial institutions. Such a department could also be responsible for restructuring state banks to make them viable.

\section{Establishing a Deposit Insurance System}

Depositors have limited information about the risk and value of bank assets, which during crisis can lead to bank runs and contagion. Deposit insurance can limit these risks by guaranteeing depositors that they will receive some, or all, of their deposited funds if their banks become insolvent or illiquid (Angkinand and Wihlborg 2008).

Myanmar's deposit insurance system is currently the responsibility of the state-owned Myanma Insurance Agency, which is also responsible for licensing other insurance agencies and supervising their activities. While it may have experience in standard insurance activities, such as life and health insurance, it has limited experience with deposit insurance, in which typical actuarial tables cannot calculate the risks, but a deep understanding of bank function, and where risks are likely, can. For this reason, deposit insurance agencies, typically, are separately funded agencies that work closely with the central bank.

Clearly, deposit insurance alone cannot be a panacea for addressing financial instability in banks. On the contrary, deposit insurance will be unsuccessful without effective bank supervision, emergency liquidity lines, and strong prudential standards implemented by the CBM. 
At the same time, if the CBM were to provide deposit insurance protection, it would design it to encourage prudential standards and discourage risky behavior (moral hazard). The central bank can achieve this by introducing penalties for risky behavior by bank owners and management. Deposit insurance protection, if available, should only cover small savers, placing shareholder equity at stake in the event of bank insolvency. To further avoid moral hazard, not only should the government refrain from issuing guarantees on an ad hoc basis for favored private or public projects, it should also insist that adequate risk-based premiums are collected to finance any provision of a deposit protection service. In Myanmar, where bank supervision and other prudential mechanisms are weak or largely absent, deposit insurance-albeit limited in what it can do-can still contribute toward the stabilization of the banking system. At the same time, it is important to remember that deposit insurance protection with low levels of coverage and/or partial insurance may not prevent bank runs (Schich 2008).

All this suggests that Myanmar should not introduce deposit insurance without carefully considering the parameters and arrangements for the scheme. Without the necessary supervisory and financial underpinnings, and adequate market discipline, the government may incur substantial fiscal losses in the event of a financial crisis. The best course would be for the government, with the help of the donor agencies or the international financial institutions, to study the feasibility of a deposit insurance, borrowing from good practice in developing countries at a similar stage in their financial development. It could also explore the possibility of a deposit insurance protection service backed by a contingent development loan drawdown option from one of the international financial institutions. ${ }^{8}$

\section{Capital Market Development}

The banking system tends to dominate financial intermediation between savers and investors in lowincome countries. Over time, however, savers in search of higher returns, and users in search of cheaper capital develop direct contacts that eventually lead to the formation of capital markets. Among capital markets, the money market precedes all others, given its central role in transmitting information about interest rates. A government bond market then tends to follow the creation of money markets, while the corporate bond and equity markets should only emerge once government bond markets are well-established.

Policies to develop capital markets should observe this sequencing. Rushing these three stages can lead to instability because risks can rapidly spread from one market to another. It is important that sequencing is done right to manage the risks of each market once they are established, before embarking on the next stage. The time horizon for completing all three stages could range from a decade to several decades.

Capital markets take a long time to develop because they require a number of prerequisites: exchange, clearance, and settlement systems; money market infrastructure; a legal system to enforce contracts; timely information about financial soundness and future prospects of companies; and adequate corporate governance standards that give investors the confidence that their investments will not be stolen (Litan, Pomerleano, and Sundararajan 2003).

8 A contingent development loan drawdown option would give authorities the option of drawing down an international financial institution loan to finance the deposit insurance scheme, if there were to be an insurance claim on the scheme in the event of sudden withdrawal of deposits from one or more domestic banks. Although international financial institutions have provided contingent loans for other purposes (such as to protect against a surge in international interest rates), there have been no loans thus far to protect against sudden deposit withdrawals. But there is no reason one cannot be designed, provided the international financial institutions are satisfied with the broader finance sector reform program. 
Measures that have long gestation periods therefore need to be started early, such as developing a domestic investor base, developing an auction system and a secondary market for treasury bonds (including an electronic securities depository), restructuring weak financial institutions, and building robust financial infrastructure (including a legal, accounting, and insolvency framework). The capacity for prudential supervision, which helps prevent risky market practices and fraud, also needs to evolve apace with the finance sector.

Policies most supportive of capital market development tend to cover market infrastructure, transparency, and corporate governance. The authorities should keep listing standards high at all times-especially when the infrastructure to support financial disclosure is weak and well-trained legal, accounting, insolvency, and securities personnel are scarce. All accounts of financial and nonfinancial institutions need to meet international accounting standards (which MFRS would do) and these accounts should be audited and made publicly available in accordance with the law. Appendix 1 on capital market development provides additional details.

\section{Policies for a More Inclusive Financial System}

\section{Branches}

Increasing the branch network of the banking system is important to increasing access to finance. The current distribution of branches across the country understandably favors urban areas, because they reach the most customers and reduce the unit costs of banking. But this neglects rural areas. Increasing the size of the branch network is important-but it is not the only answer. Myanmar's banks are also considering other, more innovative approaches, such as telebanking and mobile banking.

While the CBM has significantly eased the regulatory requirements to open new branches, considerable room for reform remains. For example, there is no need to ensure ex ante that the ratio of the capital base to the number of branches is kept constant (which requires banks to inject more capital each time they open a branch). After all, the CBM already has many other prudential regulations to safeguard the risk profile of banks. Another unnecessary requirement is the physical inspection of a new branch before approval is given. All this does is increase opportunities for corruption. Since commercial banks must compete on service standards, the CBM needs to recognize that commercial banks-especially private commercial banks-have every incentive to decide where best to locate their branches and ensure appropriate banking standards. The CBM should focus on the overall prudential standards for the banks, and occasionally, in their onsite inspections, visit banks to confirm that systems meet CBM standards.

\section{State-Owned Development Banking}

A key challenge facing Myanmar's policy makers is to increase the access of small firms and farms, and individuals or households, to financial services, especially to credit. The 2003 banking crisis and other shocks to the financial system have led to an understandable emphasis on stability and prudence in the use of collateral to underpin all loans. Consequently, however, banks deny loans to those who do not own land, even if their investments could generate high rates of return, while giving the lion's share of loans to those who own land and arguably, are in least need of financing.

Myanmar's President has placed considerable emphasis on extending loans to those who cannot afford collateral-and serious consideration is given to a state-owned credit guarantee agency that will underwrite loans to small enterprises. Such agencies are only one of many kinds of specialized 
state-owned development banks (SDBs). They are established in the belief that investments yielding high social returns can sometimes be ignored or underserviced by the private sector because of unattractive private returns or because of undue risk aversion (for example, the Gabon Development Bank and Banco Nacional de Desarrollo Agrícola in Honduras). They can specialize in one sector, cut across many sectors, or focus purely on external trade as Export-Import banks. Today, there are nearly 750 such SDBs around the world, with different characteristics and varying ownership patternsprivate, public, or mixed (UN-DESA 2005). To develop viable and sustainable business models, a growing number of publicly owned SDBs are funding commercial activities while retaining government ownership and their focus on national development (examples include the Malian Banque Nationale de Développement Agricole and the National Bank for Development in Egypt) (UN-DESA 2005).

International experience suggests success only comes to those SDBs (including credit guarantee agencies) with clearly defined mandates, high corporate governance standards, strong risk management capability, proper regulation and supervision, and a strong management team (de LunaMartínez and Vicente 2012) (Box 1). In fact, several SDBs around the world have failed due to an unviable business model, poor lending decisions, weak management, a large share of nonperforming loans, undue political interference, capture by interest groups, and lack of well-defined mandates (Gutierrez et al. 2011). In Indonesia, four development banks that collapsed because of bad loans in the 1998 Asian financial crisis - Indonesia Development Bank (Bank Pembangunan Indonesia), Bank Dagang Negara Indonesia, Bank Bumi Daya, and Bank Expor-Impor-are typical of failed development banks.

\section{Box 1: State-Owned Development Banks: Lessons of Experience}

Despite the wave of privatization of state-owned development banks (SDBs) since the 1980s, they still make up $25 \%$ on average of the total assets of banking systems around the world. In developing countries, their market share tends to be higher.

Governments have established SDBs to provide credit and other financial services to individuals, firms, and strategic sectors of the economy that private financial institutions were unable or unwilling to serve to the extent desired by policy makers. During the global financial crisis during 2008-2010, however, SDBs acquired a new role-providing countercyclical credit to private borrowers temporarily unable to access loans from private banks or capital markets.

An SDB is a state-owned financial institution with the mandate to promote socioeconomic development by financing specified economic activities, sectors, or markets.

The classic justification for SDBs is that they achieve public policy goals by correcting market failures that restrict credit to areas of the economy considered important for development and social welfare. The traditional target sectors tend to be infrastructure, agriculture, and small and medium-sized enterprises. Other, less frequent target sectors have been renewable energy, climate change adaptation and mitigation, education, low-income housing, microenterprises, innovation, and production chains.

SDBs aim to correct "information asymmetries" that occur when banks cannot obtain accurate and verifiable information about the ability and willingness of borrowers to repay a loan. A common example is small borrowers who may not have financial statements, let alone audited ones, and thus lack adequate information to demonstrate their creditworthiness. Another market failure could be the absence of systems guaranteeing compliance with financial contracts-most tend to be slow, costly, or inefficient-especially because the costs of contract compliance are higher for small borrowers than for large firms. Externalities associated with lending to a particular sector for which private banks often overestimate the risk, or underestimate the benefits, or both, are a third market failure. 
Market failures are best resolved through regulatory reforms that improve market information, increase creditor rights, ensure contract compliance, promote innovation, and expand collateral options. Governments should consider SDBs a temporary solution to increase access and serve a neglected sector while broader finance sector reforms mature. They must therefore complement, not substitute, for systemic financial reforms. Without the latter, SDBs could crowd out private banks, incur financial losses, and drain the budget, or have little development impact. To combat pressure from political interests to maintain SDBs even after they cease to be useful, the government could create sunset clauses stipulating by law when an SDB should close or make it costly to extend its existence.

SDBs do not have to provide financing directly-they can instead guarantee private lending to target sectors. State-owned credit guarantee agencies are common in several countries. Such agencies have several advantages. First, they encourage competition among private banks, which will help ensure the most efficient lending outcomes. Second, the credit guarantee reduces the burden on the borrower to offer collateral. Third, the government can serve several target sectors through one institution and can therefore concentrate scarce expertise and ensure sound risk management. Finally, as conditions change and new priorities emerge, credit guarantee agencies can alter the guarantee choices they offer private banks without incurring significant adjustment costs.

Most SDBs are capitalized through tax revenues, although low-cost foreign loans and aid (such as from the World Bank or the Asian Development Bank) can also be used. Budgetary sources of finance increase the financial autonomy of SDBs, avoid competition with other regular sources of bank funding (such as deposits and bonds), and allow SDBs to provide long-term finance for development projects at below market rates. Indeed, SDBs able to separate subsidies from their financing sources can function more as development agencies than as financial intermediaries. For example, if government financial support is in the form of an initial endowment, then SDBs will have an incentive to provide their services in a financially sustainable manner. In addition, limiting the ability of SDBs to assume financial liabilities, including by taking deposits, may limit future fiscal costs for the government.

Many SDB failures in the developing world have been caused by weak risk assessment capabilities, poor management, inadequate monitoring capacity, poor lending decisions, high nonperforming loans, undue political interference, capture by interest groups, lack of well-defined mandates, widespread corruption, and negative real interest rates leading to open-ended state subsidies.

In contrast, international experience shows that successful SDBs usually have clearly defined mandates, high corporate governance standards, strong risk management capability, proper regulation and supervision, a strong management team, and financial and legal arrangements that minimize budgetary support.

International experience also shows that good-practice policies applied to SDBs tend to increase their probability of success. For example, government should legally oblige the SDB to achieve a minimum return on capital. It should transfer SDB management to the private sector and protect it from political influence by guaranteeing independence. Governing boards should be composed entirely of independent, professionally qualified members.

The governing board could establish incentives supportive of good development outcomes through performance contracts and key performance indicators. It should insist that management use sunset clauses when launching a new program. Laws should explicitly prevent government bailout of a failed SDB. Management should encourage the private sector to share the risk of lending to underserved markets. And it should use promarket instruments when supporting SDBs.

In addition, government should introduce a legal obligation to achieve a minimum return on capital, place the development bank in the private sector under a management contract, and place independent and qualified finance professionals on the board of directors (de la Torre, Gozzi, and Schmukler 2007).

SDBs in Myanmar can help broaden access to finance and be a vehicle for countercyclical monetary policy. But authorities need to carefully craft the legal, institutional, and incentive frameworks to increase probability of success and minimize the burden on the exchequer. The government must also create organizational capabilities to manage these institutions professionally and without political interference, and implement promarket programs that supplement private sector initiatives, not substitute for them.

Source: Author. 
The biggest challenge development banks tend to face is the ability to manage risks. This reflects the difficulties they face throughout the lending cycle, which includes the assessment of prospective clients' creditworthiness, the absence of accounting standards, the way they assess risks, and their ability to enforce contracts and collect on loans or execute collateral. Other big challenges they face are financial self-reliance (over 60\% of development banks surveyed globally recently reported reliance on annual budgetary subsidies), the flexibility to acquire appropriate skills and professional managers, and political interference in decision making (de Luna-Martínez and Vicente 2012).

That is not to say that development banks cannot be successful. In fact, several in other countries have made a development impact and remained financially sound. These experiences suggest innovative ways for SDBs to improve their chances of success. ${ }^{9}$

\section{Box 2: Financing Small and Medium-Sized Enterprises}

Countries have two sets of choices to make in financing small and medium-sized enterprises (SMEs). The first is whether government should set up a state-owned development bank (SDB) specialized in SME financing or require all SDBs to include SME financing as part of operations.

The second has three options: support direct lending through SDBs, provide credit guarantees, or provide equity. In each case, low interest loans are provided to SMEs through credit or equity lines, and SDBs then refinance themselves either through the budgetary mechanism, through central bank credit lines, or through credit lines financed by bilateral or multilateral financial institutions.

SDBs can provide SMEs working capital loans, loans denominated in local or foreign currency, as well as equity financing or even venture capital funds. Whatever the type of financing, SDBs need to acquire specialized knowledge of SMEs and the sector into which they are lending, in part to keep the cost of lending within reasonable bounds (since fixed costs of information are high and loan amounts tend to be small) and to keep the nonperforming loan ratio within required prudential limits.

There is no consensus on the advantages or disadvantages of credit guarantees versus direct lending. Both tend to suffer from the same challenges of high fixed information costs, large losses from nonperforming assets, and mismanagement of programs and institutions (UNCTAD 2001). A useful mechanism to consider for exporting SMEs is for SDBs to guarantee letters of credit based on confirmed export orders and buyer letters of credit. But developing such a system requires considerable knowledge, expertise, and links with foreign banks in the major export markets. All this suggests that Myanmar focus initially on pooling expertise and systems in one SDB, make it a center of excellence, and then after a few years review the experience to decide on next steps.

Experience from other countries, such as the Industrial Development Bank of India or Malaysia's Industrial Development Finance Berhad, also suggests that SME finance needs to be accompanied with technical assistance for project development and project design to ensure the finance is productive and efficient.

Source: Author.

The government needs to link its decision to establish a development bank with its program to restructure state banks. Those state banks that will continue will need to be transformed into development banks-leaving all commercial banking to the private sector. If the government decides on a development bank arrangement, such as the Credit Guarantee Scheme for SME lending discussed in Box 2, it should do so in partnership with organizations such as the IFC or ADB, and build on the experience of other Asian countries (such as Indonesia, Malaysia, and Thailand).

9 For more insight, see Gutierrez et al. 2011 and Cihák, M. and A. Demirgüç-Kunt 2013. 


\section{Microfinance}

According to one estimate, demand for microfinance in Myanmar is four times greater than supply, ${ }^{10}$ which means that fewer than 20 out of 100 potential microfinance clients have access to formal financial services, with most people relying on family savings or costly alternatives such as informal moneylenders (Duflos et al. 2013).

It is therefore not surprising that the government has placed high priority on delivering microfinance, for which it enacted a new Microfinance Law in November 2011 (together with Notification 277 and accompanying instructions). The agency designated to license new microfinance institutions-the Myanmar Microfinance Supervisory Enterprise-has already licensed 142 microfinance providers, of which 3 are foreign and 50 have been given a license to collect deposits (which effectively makes them banks).

The capital requirements for deposit-taking microfinance institutions, at $\$ 30,000$, is very low and, if improperly managed and supervised, could cause insolvencies among microfinance agencies. Moreover, these new microfinance providers are already entering a crowded market. State banks, cooperatives, international and national nongovernment organizations, international organizations, specialized agricultural development companies, informal lenders, semiformal village revolving funds, and community funds are already in the business of providing microfinance (Appendix 2). These agencies already reach some 2.8 million borrowers. The government may therefore want to pause in issuing licenses, study the microfinance sector more carefully, review the current institutional arrangements for licensing and supervision, and rethink its strategy to provide a sustainable system of microfinance.

\section{Branchless Banking}

While increased branch banking will extend access to finance, recent innovations in branchless banking can allow Myanmar to leapfrog other countries and provide its people access to finance more rapidly and cost-effectively. Branchless banking includes a range of options that are not mutually exclusive, including the following:

i. ATMs (or bank branches in a box); banking vans (or bank branches on wheels).

ii. In-store point-of-sale systems (that permit cashless payments using credit, debit, or prepaid cards).

iii. Internet banking (permitting virtual connections with banks and their branches).

iv. Banking agents (outsourced bank branches).

v. Mobile (telephone) banking (a bank branch in a pocket).

Each of these channels has proven itself in the marketplace and countries use them to varying degrees (IFC 2012). In some cases, they have induced channel substitution, whether because of greater convenience or lower cost to the user, and have shifted transactions that would otherwise have gone through a bank branch.

Analysis of branchless banking gives clear evidence of its many benefits-and many of Myanmar's private banks are gearing up to introduce various combinations of branchless banking channels. Although still in its infancy, the Myanmar Payment Union, with 17 private banks as members, is already providing a platform for spreading an ATM network. Some banks have partnered with credit

10 "Microfinance" applies to financial services provided to low-income individuals, households, farms, and firms. 
companies to introduce credit card services, and the point-of-sale (POS) network, albeit still small, is set to grow rapidly. Now that Myanmar's telecom sector has issued two licenses for mobile telephony-to Norway's Telenor and Qatar's Ooredoo (formerly Qtel) - and with mobile phone connections poised to expand rapidly, banks will be able to explore other branchless banking avenues, including telebanking, banking agents, and POS systems.

What is the role of government-and regulation-in supporting the growth of branchless banking and ensuring that its expansion does not threaten the stability of the banking system? As the rapid expansion of Kenya's M-Pesa" system has shown, expanding access need not result in financial instability if appropriate regulatory and supervisory safeguards are combined with market liberalization policies.

In particular, authorities should continue to emphasize know-your-customer requirements for financial institutions to ensure Myanmar complies with international standards for antimoney laundering and combating the financing of terrorism initiatives.

Kenya's experience has also shown that when developing the policy framework for branchless banking, all the relevant departments of government (central bank and the ministries of finance, communications, planning and economic development) must ensure close dialogue with the private sector.

\section{SEQUENCING REFORMS FOR FINANCE SECTOR DEVELOPMENT}

Policy makers cannot implement all the actions described in the previous section at once. Indeed, and as noted, Myanmar's capacity constraints in all spheres, including in the finance sector, make it imperative that authorities sequence reforms carefully. The country cannot afford to implement reforms in the wrong order, which will simply waste effort. There may be considerable pressure from different quarters - not least from influential bankers themselves, or from the international donor community - to rush the reform process. But policy makers will need to focus on the national interest and on what makes most sense in Myanmar's particular circumstances. For example, as indicated earlier, it would make little sense to open the finance sector prematurely to $100 \%$ foreign-owned banks without first having a strong regulatory structure and building competitive and financially sound domestic banks. Similarly, premature interest rate liberalization without well-functioning supervision and well-established and well-understood prudential norms would only lead to excessive risk taking and lead eventually to financial crisis.

To develop a stable and efficient finance sector that can support long-term development needs, Myanmar should focus first on establishing strong foundations. Namely, it should put in place a legal and institutional structure that provides financial institutions with regulatory clarity and central bank services that facilitate efficient real-time clearance and settlement of interbank claims and permit sound liquidity management. Many of these initial capacity-building initiatives are eminently feasible and the authorities can implement them with the help of the international community, notably the international financial institutions (the IMF, World Bank, and ADB) and key bilateral aid agencies, especially JICA, the Department for International Development, and Australia's Department of Foreign Affairs and Trade.

1 M-Pesa is Kenya's mobile payment system. Kenyans use mobile phones for payment and banking transactions. Half of all mobile money transactions in the world take place in Kenya, where annual transfers have reached $\$ 10$ billion (Gilpin 2014). 
To this end, the government should focus on the following reforms in the short-term, namely over the next 12 months or so:

i. Start training banks and corporates to adopt the MFRS and have a clear deadline for its adoption by all banks and corporates in 2015 .

ii. Initiate implementation of a CBM electronic system for automated clearance, payments, and settlements system.

iii. Confirm donor funding and recruit international expertise to strengthen the central bank's supervision department.

iv. Prepare the legal and regulatory ground for an interbank market for liquidity management.

v. Develop market-based central bank liquidity facilities to assist banks in periods of systemic liquidity shortages.

vi. Finalize and enact the Financial Institution Law, which should include clarification on the role of FDI in the finance sector, exit policies and arrangements for banks, financial reporting requirements, the use of MFRS, and so on.

vii. Maintain the current interest rate policy. But the central bank should adjust the level of deposit and lending rates as macroeconomic conditions demand to ensure that they are positive in real terms and that the intermediation margin is adequate for banks to earn reasonable return on their capital.

viii. Permit commercial banks to compete on service standards and fees, including fees for remittances.

ix. Initiate audit of state banks - preferably by international auditors (financed by donors).

x. Audit financial regulations to determine which regulations can be eliminated safely.

xi. Refrain from establishing more banks for the time being (including giving licenses to fully foreign-owned banks).

xii. Remove unnecessary constraints to branch expansion by commercial banks.

xiii. Initiate study of legal, regulatory, and institutional needs to support the rapid expansion of branchless banking.

xiv. Review the microfinance institutions sector and the appropriateness of the current legal, supervisory, and licensing system. Temporarily stop issuance of microfinance institution licenses until the way forward is clear.

These reforms implemented over the short-term will provide the foundations for the next generation of medium-term finance sector reforms, which the government should implement over the subsequent 3 years. These reforms could include the following actions:

i. Enforce the MFRS for banks (which should be the responsibility of the central bank) and corporates (which should be the responsibility of the Directorate for Investment and Company Administration in the Ministry of Planning and National Development).

ii. Fully implement the interbank electronic clearance, payments, and settlement system.

iii. Introduce an auction system and a secondary market for treasury bonds.

iv. Introduce an interbank market to permit better liquidity management.

v. Develop a market-based government bond market and develop benchmark interest rates.

vi. Launch an intensified CBM supervision capacity building program with international expertise.

vii. Study the introduction of a deposit insurance arrangement.

viii. Re-launch a reformed microfinance strategy.

ix. Introduce regulations for branchless banking.

x. Maintain the current policy of fixed interest rates for at least 3 years (adjusted as appropriate for macroeconomic conditions), but assess the appropriateness of, and prepare for, moving to 
the second stage of interest rate liberalization-namely a floor for lending rates and a ceiling for deposit rates.

xi. Work with the World Bank and ADB to prepare a state bank restructuring strategy, based on the audit results of the four state banks. Allow one or, at most, two state development banks to survive. Give them clear mandates, adequate financial resources, independent and professional management, a corporate governance framework that protects them against political interference, and an incentive structure that encourages achievement of their mandate but combines it with prudent financial management.

\section{Intersection of Finance Sector Reforms with Other Reforms}

Finance sector reforms will be taking place alongside reforms in other sectors, and it is important that they are well-coordinated. Thus, reforms to monetary and fiscal policies will have a bearing on the pace and sequencing of finance sector reforms. Similarly, policy makers should undertake reforms in the real sector (such as trade, agriculture, land, manufacturing, and investment licensing reforms) in coordination with finance sector reforms. Ideally, real sector reforms should precede finance sector reforms so that any changes in relative prices do not weaken the portfolio of banks. In Myanmar's current situation, however, pragmatism demands that government should move ahead with finance sector reforms even as it is implementing real sector reforms.

Fiscal reforms will be critical for the smooth development of the finance sector for several reasons. First, better fiscal performance places less pressure on the banking system to perform quasifiscal functions. It is better that government agencies implement development programs with high social but low financial rates of return, and good fiscal performance ensures they can be financed through the budgetary system.

Second, good fiscal performance allows targeted lending programs through the banking system to use budget-financed interest rate incentives rather than administratively suppressed interest rates, which impose a tax on depositors.

Third, smaller fiscal deficits reduce the likelihood of "crowding out" the private sector, as more financial resources can be channeled through the banking system to private businesses rather than to the government. This helps the government avoid forced placement of government debt in banks (which taxes the banking system rather than encourages it).

Fourth, greater availability of fiscal resources will give the government more options when it comes to restructuring state bank balance sheets and, if some need to be closed, assisting with meeting their outstanding net liabilities.

Finally, sound fiscal management can prove helpful in times of financial crisis when the government may need to recapitalize a bank for strategic purposes and systemic stability. 


\section{APPENDIX 1: CAPITAL MARKET DEVELOPMENT}

\section{A. Money Market}

The money market forms the base of the capital market by supporting trading in the most liquid instruments, including overnight loan facilities. To build a money market in Myanmar, the central bank needs to introduce monetary instruments (such as treasury bills, central bank bills, and central banks auctions) that help banks (and eventually nonbank financial institutions) manage their liquidity. They should also apply reserve requirements as an initial means to control liquidity, and design a framework by which banks can access the central bank's standing liquidity facilities. The money market develops as the central bank buys and sells short-term funds, adjusts the appropriate level of required reserves in line with macroeconomic needs, and alleviates systemic liquidity shortages when they arise. The primary objective, however, should be to encourage banks to trade money and other liquid financial instruments among themselves, and only when these prove inadequate should banks resort to trading with the central bank.

Repurchase agreements (or repos) are a key instrument in money markets and an important method by which the central bank can exert indirect monetary control and influence liquidity in the financial system. ${ }^{2}$ Repos become particularly important when counterparty credit risks are high (as they are in Myanmar), because they are a form of collateralized lending. The repo market, however, requires an underlying legal structure. Participants should meet key prudential financial criteria-such as minimum capital requirements and the ability to meet mandated liquidity ratios-and should be subject to central bank oversight.

\section{B. Government Bond Market Development}

The government bond market is the next stage of capital market development, and its formation normally follows the creation and development of the money market. The government bond market provides a market-determined term structure of interest rates that reflects the opportunity cost of money at different maturities. The development of a term structure of interest rates in relatively riskfree government bonds helps the introduction and development of new financial products of different maturities that can assist lenders and borrowers manage risk better and provide benchmark discount rates that assist market participants undertake project cost-benefit analysis and calculate one measure of the market value of companies. A government bond market also facilitates the conduct of monetary policy by aiding with the transmission mechanism for interest rates and, together with the money market, gives financial institutions more instruments with which to manage liquidity.

The development of a government bond market usually precedes the formation of corporate equity and bond markets. The following are prerequisites, however, for government bond markets to fulfill their required role:

i. Macroeconomic stability;

ii. An efficient and liquid money market;

iii. A clear articulation and announcement of the government's debt strategy;

iv. A credible and regular supply of government debt securities to the market;

v. The presence of many potential investors;

12 Repurchase agreements are the sale of securities combined with an agreement for the seller to buy back the securities later at a higher price, with the difference in the sale and the repurchase price acting as an implicit interest rate. 
vi. A neutral policy toward capital taxation that makes no distinction between incomes from different types of financial investments (bank deposits, government bonds, corporate equity, and other financial instruments);

vii. A settlement infrastructure and regulatory framework that facilitates secondary trading; and

viii. An effective and transparent legal framework that provides the legal underpinning to financial contracts implicit in primary and secondary market trading.

To establish a government bond market, the government must be committed to financing its borrowing requirement at market-based prices, permanently move away from forced placement, and ensure standardized government securities (apart from maturity) with a concentration in a limited number of popular benchmark maturities. Key government measures would involve establishing a primary dealer system, fostering repurchase (repo) transactions, and building benchmark security issues.

The infrastructure for spot primary and secondary trading should be simple, safe, and secureand be able to handle volumes consistent with market needs. Because Myanmar's infrastructure is still weak, primary traders should be required to meet a minimum bidding commitment for primary trades and publicly offer two-way quotes for secondary trades, while building distribution channels, acting as intermediaries, and providing market information such as prices, volumes, and spreads. In return, they should be granted certain privileges for their market-making role-including exclusive or restricted access to auctions, access to noncompetitive bidding, and liquidity support from the central bank. At the same time, the authorities should take care that primary dealers do not collude to distort the price of securities for their benefit.

The usual sequence is to start with short-term bonds with maturities similar or close to instruments available in the money market; but the transition to longer-term fixed rate debt must be gradual. It is important that bond markets are liquid at all times, which means active participation by intermediaries that have adequate capitalization and adopt appropriate risk management strategies, as well as an efficient market infrastructure, including well-designed securities settlement arrangements.

\section{Corporate and Equity Market Development}

Corporate bond and equity market development should be the last phase of capital market development and should be undertaken only when the money market and government bond markets are functioning smoothly. Corporate bond markets would use the same infrastructure as government bonds, but equity markets will have different market infrastructure needs. Both markets help diversify sources of corporate finance away from banks and permit the availability of longer maturity funds, which banks typically do not provide.

It is important that corporate bond and corporate equity market development is balanced. Corporate bond markets without equity markets could cause excessive leverage; equity markets without bond markets would not flourish as finance would be too expensive. Both require accurate and timely disclosure of financial information from the issuer to make informed investment decisions and assess creditworthiness. The legal and institutional infrastructure should protect investors against fraud and misrepresentation.

In small economies like Myanmar, it is difficult to find enough large companies that can be listed on the stock exchange. Those that list will not only cede some management control, but also experience additional costs for accounting, legal, and reporting requirements and have less flexibility in 
decision making. It is more probable that, as private companies grow larger, they will gradually list on the stock exchange, initially with a small number and then later with a broader base of shareholders.

When the number of total shares in the stock exchange is small, it makes considerable sense to have periodic markets instead of continuous markets as a means of bringing together all trades at one time, thereby deepening the market for a short period and enhancing the market's liquidity.

Equity instruments are private property instruments, which require mechanisms to enforce legal ownership rights and facilitate ownership transfer. Court systems need to be sufficiently sophisticated in dealing with complex commercial claims and be able to resolve disputes quickly and fairly. The court system, corporate governance structures, and the quality of financial disclosure statements together should protect minority shareholders against related party transactions.

Equity markets have traditionally developed through stock exchange mechanisms that bring together investors temporally and increase the liquidity of financial instruments. Settlement systems need to be safe and efficient-and Myanmar needs to consider carefully the 2001 recommendations of the Basel Committee on Payment and Settlement Systems (CPSS) and the International Organization of Securities Commissions (IOSCO) that set the international standard for clearing and settlement systems (BIS and IOSCO 2001). 
APPENDIX 2: MICROFINANCE PROVIDERS IN MYANMAR

\begin{tabular}{|c|c|c|c|c|c|c|c|c|c|c|}
\hline Category & Institutions & $\begin{array}{l}\text { Number of } \\
\text { Branches/Outlets }\end{array}$ & $\begin{array}{l}\text { Number of } \\
\text { Borrowers }\end{array}$ & $\begin{array}{l}\text { Outstanding Loan } \\
\text { Portfolio } \\
\text { (kyat) }\end{array}$ & $\begin{array}{c}\text { Average Loan } \\
\text { Outstanding } \\
\text { (kyat) }\end{array}$ & $\begin{array}{l}\text { Number of } \\
\text { Deposit } \\
\text { Accounts }\end{array}$ & $\begin{array}{c}\text { Total Savings } \\
\text { (kyat) }\end{array}$ & $\begin{array}{c}\text { Average Deposit } \\
\text { Size } \\
\text { (kyat) }\end{array}$ & Regulated & $\begin{array}{l}\text { Supervisory } \\
\text { Agency }\end{array}$ \\
\hline \multirow{2}{*}{$\begin{array}{l}\text { State-owned } \\
\text { bank }\end{array}$} & $M_{A D B}{ }^{a}$ & 205 & $1,420,000$ & $84,000,000,000$ & 59,155 & $1,720,000$ & $86,891,840,000$ & 50,519 & Yes & $\begin{array}{l}\text { Ministry of } \\
\text { Finance } \\
\text { and Revenue }\end{array}$ \\
\hline & $M S L E^{b}$ & 143 & 208,778 & $31,341,790,000$ & 150,120 & $\ldots$ & $\ldots$ & $\ldots$ & Yes & $\begin{array}{l}\text { Ministry of } \\
\text { Finance } \\
\text { and Revenue }\end{array}$ \\
\hline Private bank & MLFDB $^{\mathrm{b}}$ & 53 & $\ldots$ & $\ldots$ & $\cdots$ & $\ldots$ & $\ldots$ & $\ldots$ & Yes & $\begin{array}{l}\text { Central Bank of } \\
\text { Myanmar }\end{array}$ \\
\hline \multirow{8}{*}{$\begin{array}{l}\text { Nongovernment } \\
\text { organization }\end{array}$} & PACT-UNDP & 105 & 365,410 & $52,701,000,000$ & 144,224 & 420,133 & $10,930,000,000$ & 30,000 & No & $\ldots$ \\
\hline & $\mathrm{PACT}^{\mathrm{c}}$ & 16 & 57,128 & $4,234,502,910$ & 74,123 & $\ldots$ & $x_{1}$ & $\ldots$ & Yes & $\begin{array}{l}\text { Microfinance } \\
\text { Supervisory } \\
\text { Enterprise }\end{array}$ \\
\hline & $\mathrm{GRET}^{\mathrm{d}}$ & 4 & 6,155 & $840,041,000$ & 136,481 & \multicolumn{3}{|c|}{ Nondeposit taking microfinance institution } & Yes & $\begin{array}{l}\text { Microfinance } \\
\text { Supervisory } \\
\text { Enterprise }\end{array}$ \\
\hline & Save the Children ${ }^{e}$ & $\ldots$ & 7,737 & $367,747,782$ & 47,531 & 7,737 & $25,975,513$ & 3,357 & Yes & $\begin{array}{l}\text { Microfinance } \\
\text { Supervisory } \\
\text { Enterprise }\end{array}$ \\
\hline & World Vision $^{\dagger}$ & 12 & 13,282 & $1,910,033,328$ & 143,806 & $\ldots$ & $\ldots$ & $\ldots$ & Yes & $\begin{array}{l}\text { Microfinance } \\
\text { Supervisory } \\
\text { Enterprise }\end{array}$ \\
\hline & Proximity Design ${ }^{g}$ & 8 & 16,000 & $3,113,831,000$ & 194,614 & $\ldots$ & $\ldots$ & $\ldots$ & Yes & $\begin{array}{l}\text { Microfinance } \\
\text { Supervisory } \\
\text { Enterprise } \\
\end{array}$ \\
\hline & $\mathrm{AMDA}^{\mathrm{h}}$ & $\ldots$ & 1,510 & $55,109,960$ & 36,497 & $\ldots$ & $\ldots$ & $\ldots$ & No & $\ldots$ \\
\hline & Total $^{h}$ & $\ldots$ & 1,197 & $165,077,000$ & 137,909 & $\ldots$ & $\ldots$ & $\ldots$ & No & \\
\hline \multirow[b]{2}{*}{ Cooperatives } & $\begin{array}{l}\text { Central } \\
\text { Cooperative } \\
\text { Society }^{i}\end{array}$ & 46 & 32,851 & $1,125,690,000$ & 34,267 & 32,851 & $340,340,000$ & 10,360 & Yes & $\begin{array}{l}\text { MSE / Central } \\
\text { Cooperative } \\
\text { Society }\end{array}$ \\
\hline & $\begin{array}{l}\text { Financial } \\
\text { Cooperatives - } \\
\text { Union of Savings } \\
\text { and } \\
\text { Credit Federation }\end{array}$ & 1,625 & 476,632 & $16,500,000,000$ & 34,618 & 476,632 & $24,200,000,000$ & 50,773 & Yes & $\begin{array}{l}\text { Central } \\
\text { Cooperative } \\
\text { Society }\end{array}$ \\
\hline \multirow{2}{*}{$\begin{array}{l}\text { Specialized } \\
\text { Agricultural } \\
\text { Companies }\end{array}$} & $\begin{array}{l}\begin{array}{l}\text { Rice specialization } \\
\text { companies }^{j}\end{array} \\
\end{array}$ & 38 & 57,502 & $20,092,708,226$ & 349,426 & $\ldots$ & $\ldots$ & $\ldots$ & No & $\ldots$ \\
\hline & $\begin{array}{l}\text { Other agricultural } \\
\text { specialized } \\
\text { companies }^{j}\end{array}$ & 22 & 140,000 & $20,000,000,000$ & 142,857 & $\ldots$ & $\ldots$ & $\ldots$ & No & $\ldots$ \\
\hline Women's union ${ }^{k}$ & & 16 & 4,800 & $48,000,000$ & 10,000 & $\ldots$ & $\ldots$ & $\ldots$ & No & $\ldots$ \\
\hline
\end{tabular}


Appendix 2 continued

\begin{tabular}{|c|c|c|c|c|c|c|c|c|c|c|}
\hline Category & Institutions & $\begin{array}{c}\text { Number of } \\
\text { Branches/Outlets }\end{array}$ & $\begin{array}{c}\text { Number of } \\
\text { Borrowers }\end{array}$ & $\begin{array}{r}\text { Outstanding Loan } \\
\text { Portfolio } \\
\text { (kyat) }\end{array}$ & $\begin{array}{c}\text { Average Loan } \\
\text { Outstanding } \\
\text { (kyat) }\end{array}$ & $\begin{array}{l}\text { Number of } \\
\text { Deposit } \\
\text { Accounts }\end{array}$ & $\begin{array}{l}\text { Total Savings } \\
\text { (kyat) }\end{array}$ & $\begin{array}{c}\text { Average } \\
\text { Deposit Size } \\
\text { (kyat) }\end{array}$ & Regulated & $\begin{array}{l}\text { Supervisory } \\
\text { Agency }\end{array}$ \\
\hline $\begin{array}{l}\text { Union solidarity } \\
\text { Development } \\
\text { Association }\end{array}$ & & 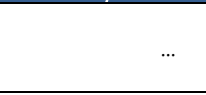 & 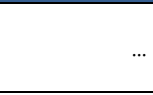 & 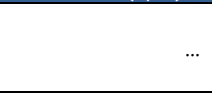 & 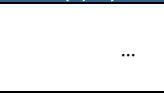 & $\ldots$ & 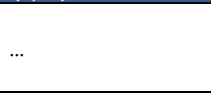 & $\ldots$ & $\ldots$ & $\ldots$ \\
\hline $\begin{array}{l}\text { Community- } \\
\text { based } \\
\text { organizations' }\end{array}$ & & $\ldots$ & $\ldots$ & $\ldots$ & $\ldots$ & $\ldots$ & $\ldots$ & $\ldots$ & No & $\ldots$ \\
\hline TOTAL & & 2,293 & $2,808,982$ & $236,495,531,206$ & 119,763 & $2,657,353$ & $122,388,155,513$ & & & \\
\hline
\end{tabular}

$\ldots=$ not available, AMDA = Association of Medical Doctors of Asia, GRET = an international nongovernment organization governed by French laws, MADB $=$ Myanma Agricultural Development Bank, MLFDB = Myanma Livestock and Fisheries Development Bank, MSLE = Myanma Small Loans Enterprise, PACT = Partner Agencies Collaborating Together, UNDP = United Nations Development Programme.

Notes: Because overall data availability and accuracy is low, users should view the above figures with caution.

Data as of March 2012 provided by MADB.

Data as of March 2011 from CBM.

Data as of September 2012 from UNDP for PACT UNDP and as of end October 2012 from PACT for PACT.

Data as of October 2012 from GRET.

e Data as of October from Save the Children. Savings are from members only

${ }^{f}$ Data from World Vision MFI, 9 November 2012

${ }^{8}$ Data from Proximity Design, October 2012.

h Data as of end-September 2009 from ACTED and Banking with the Poor Network (2009).

Data as of May 2012 from CCS. Data for Microcredit Cooperatives ads of September 2011.

Data as of September 2011 from the Myanmar Rice Association.

Estimates provided during interview with MADB, June 2012.

No data available.

Source: Duflos et al. 2013 


\section{REFERENCES}

Agoraki M. E., M. D. Delis, and F. Pasiouras. 2009. Regulations, Competition and Bank Risk-Taking in Transition Countries. MPRA Paper No. 16495. Munich Personal RePEc Archive.

Angkinand, A. and C. Wihlborg. 2008. Deposit Insurance Coverage, Ownership, and Banks' RiskTaking in Emerging Markets. Working paper. http://digitalcommons.chapman.edu/ cgi/viewcontent.cgi? article $=1026 \&$ context=business_articles

Bank for International Settlements (BIS) and International Organization of Securities Commissions (IOSCO). 2001. Recommendations for Securities Settlement Systems. Basel.

Caprio, G. 2010. Safe and Sound Banking: Role for Countercyclical Regulatory Requirements? Finlawmetrics 2010 Conference Paper. http://papers.ssrn.com/sol3/papers.cfm?abstract_id $=1545870$

Central Bank of Myanmar. 2014. Information on the Structure of Financial System in Myanmar.

Čihák, M. and A. Demirgüç-Kunt. 2013. Rethinking the State's Role in Finance. World Bank Policy Research Working Paper No. 6400. Washington, DC: World Bank.

Claessens, S., S. Demirgüç-Kunt, and H. Huizinga. 2001. How Does Foreign Entry Affect the Domestic Banking System? Journal of Banking and Finance. 25 (5). pp. 891-911.

de la Torre, A., J. C. Gozzi, and S. L. Schmukler. 2007. Innovative Experiences in Access to Finance: Market Friendly Roles for the Visible Hand? World Bank Policy Research Working Paper No. 4326. Washington, DC: World Bank.

de Luna-Martínez, J. and C. L. Vicente. 2012. Global Survey of Development Banks. World Bank Policy Research Working Paper No. 5969. Washington, DC: World Bank.

Duflos, E., P. Luchtenburg, L. Ren, and L. Y. Chen. 2013. Microfinance in Myanmar: Sector Assessment. International Finance Corporation Advisory Services in East Asia and the Pacific and Consultative Group to Assist the Poor. January.

Egreteau, R. 2009. The Repression of the August 8-12 1988 (8-8-88) Uprising in Burma/Myanmar. Online Encyclopedia of Mass Violence. http://www.massviolence.org/The-repression-of-theAugust-8-12-1988-8-8-88-uprising-in

Elevenmyanmar.com. 2013. Myanmar Housing Development Bank to Open Next Month. 28 August. https://elevenmyanmar.com/index.php?option=com_content\&view=article\&id=3220:myanm ar-housing-development-bank-to-open-next-month\&catid=33\&Itemid=356

Federal Register. 2003. Imposition of Special Measures against Myanmar Mayflower Bank and Asia Wealth Bank as Financial Institutions of Primary Money-Laundering Concern. Federal Register, The Daily Register of the United States Government. www.federalregister.gov/articles/2003/11/ 25/03-29288/imposition-of-special-measures-against-myanmar-mayflower-bank-and-asiawealth-bank-as-financial 
Gilpin, L. 2014. The World's Unlikely Leader in Mobile Payments: Kenya. TechRepublic. 20 March. http://www.techrepublic.com/article/the-worlds-unlikely-leader-in-mobile-payments-kenya/

Gutierrez, E., H. P. Rudolph, T. Homa, and E. B. Beneit. 2011. Development Banks: Role and Mechanisms to Increase Their Efficiency. World Bank Policy Research Working Paper No. 5729. Washington, DC: World Bank.

Hermes, N. and R. Lensink. 2013. Financial Development and Economic Growth. New York: Routledge.

International Finance Corporation (IFC). 2012. Innovations in Retail Payments Worldwide: A Snapshot-Outcomes of the Global Survey on Innovations in Retail Payment Instruments and Methods. Financial Infrastructure Series: Payment Systems Policy and Research. Washington, DC.

International Monetary Fund (IMF). 2013a. Myanmar: Article IV Consultation and First Review under the Staff-Monitored Program. Washington, DC.

2013b. Financial Access Survey. Washington, DC.

Kloeppinger-Todd, R. and T. M. Sandar. 2013. Rural Finance in Myanmar. Background Paper 3 commissioned as part of a Strategic Agricultural Sector and Food Security Diagnostic for Myanmar, led by Michigan State University in partnership with the Myanmar Development Resource Institute-Centre for Economic and Social Development (MDRI-CESD).

Litan, R. E., M. Pomerleano and V. Sundararajan. 2003. The Future of Domestic Capital Markets in Developing Countries. Washington, DC: Brookings Institution Press.

Mahtani, S. 2013. Myanmar Bank, MasterCard Launch Cash Card. Wall Street Journal. 18 October.

Min, W. H. 2011. International and Cross Border Bank Lending Implication in SEACEN: Balance Sheet Perspective in Myanmar. In R. Y. Siregar and V. Pontines, eds. International and Cross-Border Bank Lending and Implications in SEACEN Economies: Balance Sheet Perspective. Kuala Lumpur: The South East Asian Central Banks Research and Training Center.

Nijathaworn, B., S. Chaikhor, S. Chotika-arpa, and S. Sakkankosone. 2015. Monetary Policy and Foreign Exchange Management: Reforming Central Bank Functions in Myanmar. Forthcoming ADB Economics Working Paper Series. Manila: Asian Development Bank.

Organisation for Economic Co-operation and Development (OECD). 2003. FATF Decides to Impose Counter-Measures on Myanmar. www.fatf-gafi.org/countries/j-m/myanmar

Schich, S. 2008. Financial Turbulence: Some Lessons Regarding Deposit Insurance. Financial Market Trends. Paris: Organisation for Economic Co-operation and Development.

The Irrawaddy. 2005. Myanmar Universal Bank Taken Over. 8 August. http://www2.irrawaddy.org/ article.php?art_id $=4875$ 
Thuya, M. 2013. UK Govt, Standard Chartered Bank Look to Build Myanmar's Financial Sector," Mizzima. 19 July. http://archive-3.mizzima.com/business/investment/item/9713-uk-govtstandard-chartered-bank-look-to-build-myanmar-s-financial-sector/9713-uk-govt-standardchartered-bank-look-to-build-myanmar-s-financial-sector

Turnell, S. 2009. Fiery Dragons: Banks, Moneylenders and Microfinance in Burma. Copenhagen: NIAS Press.

United Nations Conference on Trade and Development (UNCTAD). 2001. Improving the Competitiveness of SMES in Developing Countries: The Role of Finance to Enhance Enterprise Development. New York and Geneva.

United Nations Department of Economic and Social Affairs (UN-DESA). 2005. Rethinking the Role of National Development Banks. A background paper for Ad Hoc Expert Group Meeting on Rethinking the Role of National Development Banks. 1-2 December. New York.

World Bank. World Development Indicators. http://data.worldbank.org/data-catalog/world-developmentindicators 


\section{Developing Myanmar's Finance Sector to Support Rapid, Inclusive, and Sustainable Economic Growth}

The finance sector is the lifeblood of any economy and its smooth and efficient functioning is central to strong economic growth and development. This paper presents broad outlines of a reform strategy to develop a well-functioning financial system that supports rapid and inclusive growth in Myanmar.

\section{About the Asian Development Bank}

ADB's vision is an Asia and Pacific region free of poverty. Its mission is to help its developing member countries reduce poverty and improve the quality of life of their people. Despite the region's many successes, it remains home to the majority of the world's poor. ADB is committed to reducing poverty through inclusive economic growth, environmentally sustainable growth, and regional integration.

Based in Manila, ADB is owned by 67 members, including 48 from the region. Its main instruments for helping its developing member countries are policy dialogue, loans, equity investments, guarantees, grants, and technical assistance.

$\mathrm{ADB}$ 